\title{
Newspaper reporting of the April 2007 eruption of Piton de la Fournaise, part 2: framing the hazard
}

\author{
Andrew J. L. Harris ${ }^{1 *}$ and Nicolas Villeneuve ${ }^{2,3}$
}

\begin{abstract}
An analysis of the front pages of 120 consecutive editions of the local newspaper for the island of La Réunion (France), "Le Journal de L'lle de La Réunion", published before, during and after the April 2007 eruption of Piton de la Fournaise reveals that its front page is an ideal vehicle for maximizing information delivery and recall during a volcanic eruption. Supported by flash tests, and by cross-checking with a content analysis of information given within the newspaper, we find that the front page is an effective gauge for the hazard frame which, for the case examined here, involved six volcanic hazards (pit-crater collapse, lava flows, gas, air fall, ocean entry lava flow and bench collapse), as well as the issue of evacuation. We found that crater collapse and lava flow hazards were framed using their natural colors and clear imagery of the phenomenon, tied to context-setting explanations within the newspaper. However, for lava flows in particular there was an element of spectacle and promotion of sightseeing, with photographs always featuring sightseers invariably taking photographs. After the end of the eruption reporting became almost entirely focused on tourists and sightseeing. Gas and ash fall hazard were framed using images and words of the victims, so that it became worrying and frightening, and associated with panic. As a result, the volcano itself became portrayed as a monster, and the situation for the impacted population became "apocalyptic" and "hellish". This probably contributed to the evacuation measures being described as confused and pointless, with the morale of the impacted population suffering accordingly. The ocean entry and bench collapse had no frame at all, and became associated with the dead, exotic fish that were collected; this hazard thus being framed as an interesting curiosity rather than a volcanic hazard. The front page-tracking model followed here could guide future educative measures during volcanic crises by quickly identifying, on the basis of front page analysis, hazards that are appropriately conveyed versus those that are poorly portrayed. Responses to rectify a poor frame can include reactive scientific advertising, a route that is used commonly by businesses seeking to boost sales by taking timely advantage of a developing newspaper frame, and distribution of appropriately designed and timed press releases.
\end{abstract}

Keywords: The press, Front-page, Images, Headlines, Short-term memory, Hazard-communication, Volcanic eruption

\section{Introduction}

Through whatever mass media avenue news is received by a reader, viewer or listener the message will have been shaped by the communication route that the information has taken between the source and the receiver (e.g., Rosten 1937; Cater 1959; Cohen 1963). Following the social amplification of risk framework, the mass media plays a pivotal role as a "station" for relaying "signals"

\footnotetext{
* Correspondence: andrew.harris@uca.fr

'Université Clermont Auvergne, CNRS, IRD, OPGC, Laboratoire Magmas et

Volcans, 6 Avenue Blaise Pascal, 63178 Aubière, France

Full list of author information is available at the end of the article
}

which construct public representations of risk (Kasperson et al. 1988). The mass media thus becomes an agent through which society learns about risks, hazards and environmental disasters (Kasperson and Kasperson 1996). In this sense, the newspaper is one mass media outlet that can act as a filter that sits at the center of a communication system and operates to shape the perception of a hazard amongst the readership. Through placement, selection (of story, data and source), exaggeration, omission and preference the newspaper places bias, slant and spin into the information received (Harris 2015a) thereby setting an 
agenda (McCombs 2014) and framing the news (Reese et al. 2010). McCombs (2014) argued, for example, that newspapers,

"communicate a host of cues about the relative salience of the topics on their daily agenda. The lead story on page 1, front page versus inside page, the size of the headline, and even the length of the story all communicate the salience of topics."

These cues are laid out as part of the newspaper design and will influence what the readership thinks about and how they think about it (McCombs and Shaw 1972; $\mathrm{Vu}$ et al. 2014). Cohen (1963), for example, concluded that in providing such cues the press,

"may not be successful much of the time in telling its readers what to think, but is stunningly successful in telling its readers what to think about."

The public can then use such cues to organize their own agendas and to decide which topics are important (McCombs 2014). Bogart (1955) thus argued that "the mass media provide a natural source of conversational material," with the content providing an "array of collective images" that can be "introduced into conversation." That is, the way in which the information is given "frames" the event, influencing the perception of that event amongst the recipient population (Reese et al. 2010). In hazard communication and education it is fundamental that we define the components of such frames and recognize the message thereby communicated so as to allow an understanding of the readership's perception of, for example, a volcanic eruption impacting their community. For example, how will the reader viewing the three front pages of Figs. 1, 2 and 3-all of which were published in the local newspaper that serves the Island of Réunion during the April 2007 eruption of Piton de la Fournaise-view the volcanologist, volcanology and the ongoing volcanic emergency?

Our aim here is thus to assess the effectiveness of newspaper design in framing risk, hazard and response during a volcanic eruption, using the April 2007 eruption of Piton de la Fournaise (La Réunion, France) as our case study. This was the largest historical eruption of Piton de la Fournaise (Staudacher et al. 2009), with a short initial phase which began on 30-31 March 2007 being followed by a main phase that began on 2 April. While heavy tephra fall affected an area to the SE of the vent, gas effects were felt as far away as Mauritius (220 km to the NNE) and the village of Le Tremblet was evacuated (see Part 1 of this study). The eruption continued until 1 May 2007, cutting the island perimeter road, causing two major collapses of the Dolomieu Crater, setting up a major ocean entry
(Staudacher et al. 2008), and leaving a deep and lasting impression in the minds of the impacted population (Payet 2007). Le Journal de L'Ile de La Réunion (JIR) is one of the two main island newspapers, and between February and May of 2007 hazard-related information appeared on the front pages of the JIR on 34 out of the 120 publication days and accounted for $21.94 \mathrm{~m}^{2}$ of newspaper space (see part 1 of this study Harris \& Villeneuve, 2018). As we argue in Part 1, the opportunity to communicate, and thereby also educate on, volcanic hazard was thus maximized. Here we carry out a content analysis of this published information, focusing on the format of the messages displayed on the front page of the JIR, to assess the way in which that information was framed. This information, following the social amplification of risk framework (SARF) of Kasperson et al. (1988), and as evolved by Kasperson (1992), Kasperson and Kasperson (1996) and Kasperson et al. (2003), will inform on how the risk or hazard is perceived by the receiver (i.e., the readership) and whether or not the risk is amplified or attenuated. The hazard frame during a volcanic crisis thus needs to be defined and tracked if we are to understand how information is received and perceived by newspaper (and other mass media) readerships and, most importantly, how we can better communicate the desired message to the wider population during a volcanic emergency.

\section{Framing volcanic hazard}

Rowe et al. (2000) argued that, while the quantity of coverage of hazards will be a major influence on risk perception amongst an incident population, the way in which the media present the hazard information will also influence reader perceptions. That is, the media will report the hazard in such a way so as to encourage a certain perception of the event (e.g., Dawson and Lyons 2003; Washer 2004; Wallis and Nerlich 2005; Höijer et al. 2006). Thus, in the context of content analysis, framing becomes defined as the presentation of information in such a way that a particular interpretation, view or evaluation of an event is promoted (Entman 2004). This is the definition of "frame" and "framing" applied here, where information regarding the volcanic hazard passes through a series of filters that mean that information is organized and described (Kahneman and Tversky 1984) in a way so as to promote a particular interpretation (Harris 2015a).

The front page layout of a newspaper, for example, is carefully designed to display a clear message that makes a person want to buy the newspaper, while giving the reader something to think about (Rowe et al. 2000). In providing cues through pictures and colors, plus through delivery of a few, large, bold, evocative words in the headlines, newspaper front pages are extremely effective in delivering an immediate message (Naccarato and Neuendorf 1998); 


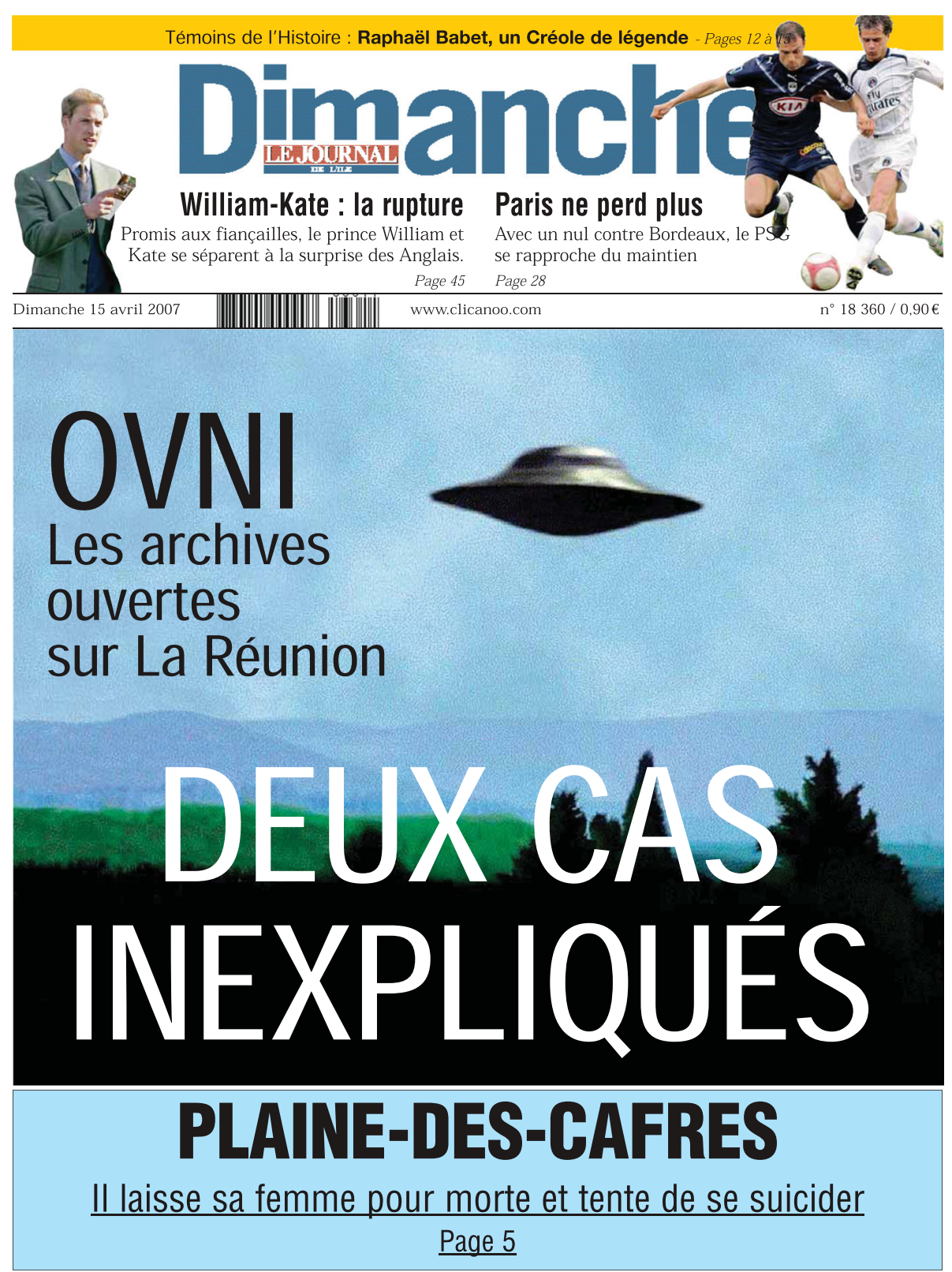

Fig. 1 Front page of JIR on 15 April 2007 (N 18360) featuring a potential hazard (OVNI is French for Unidentified Flying Object-“UFO") not related to the natural hazard considered here, where this newspaper was published on day 13 of Piton de la Fournaise's April 2007 eruption

thereby framing the featured event (Reese 2010) and downplaying-through selecting and highlighting certain events over others (Entman 2004)-another (c.f. Figs. 1, 2 and 3). It is quite clear, for example, how the selection and use of images in the examples of Figs. 1, 2 and 3-all of which were published during the April 2007 eruption of Piton de la Fournaise-frame the natural hazard. In the case of Fig. 1 the event in which we are interested in communicating (the volcanic eruption and its hazard) has no presence and thereby goes unnoticed in spite of continued impact on communities in the SE of the island; the featured focus being an eye-catching distraction that will likely leave a lasting impression in the viewer's mind. In Fig. 2, the eruption is a secondary frame which is easily missed-being only given in text above a primary frame which is framed in image and text and which dominates the page. Again, both the text and imagery of the featured focus will likely dominant the viewer's attention. In Fig. 3, the volcanic hazard becomes the primary frame. In all cases, the primary frame has been set up through design. 


\section{SAMEOD 31 MARS $200 \%$

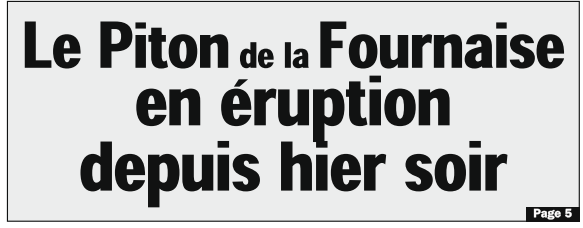

|||||||||||||||||||||||||| $\mid N \cdot 18345 \cdot 1 €$

www.clicanoo.com
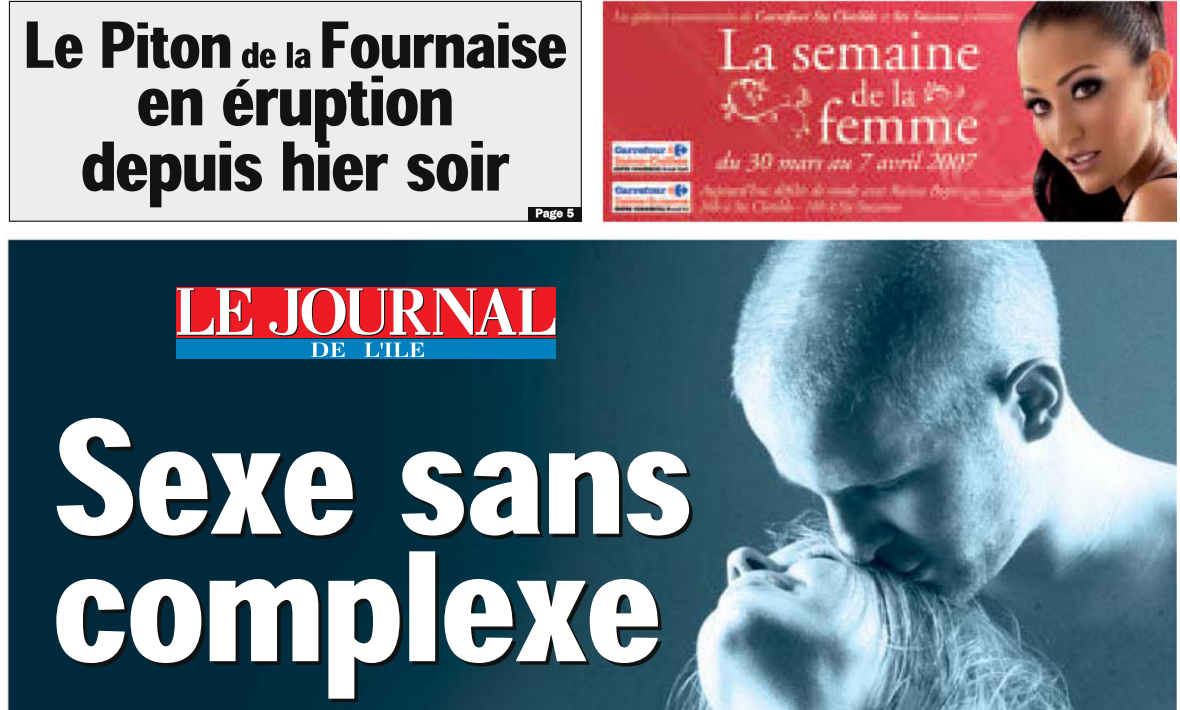

A la Réunion, les femmes sont devenues presque aussi actives que les hommes

Pages 16 à 18
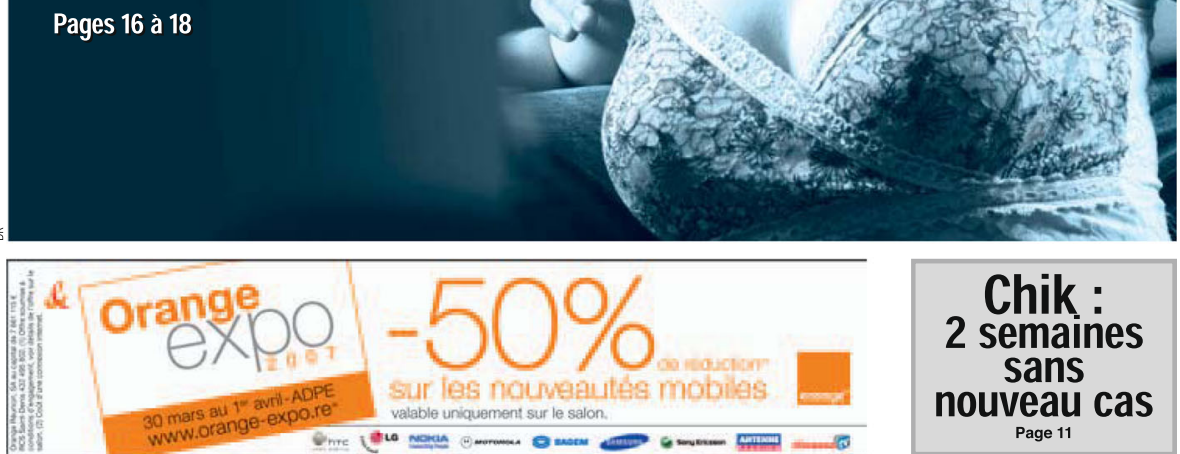

Fig. 2 Front page of JIR on 31 March 2007 ( $N^{\circ}$ 18345). The onset of eruptive activity is announced as a front page header (top-right text box which reads "Piton de la Fournaise in eruption since last evening") with the reader being referred to the internal, page 5, report. However, the main headline and image is not related to the onset of the eruption, and dominates the reader's attention

\section{Designing the news}

It is well-known that the front page of a newspaper provides an impression which is "immediate and determinant" on the reader, and needs to "excite the curiosity" of the reader (Martin-Lagardette 2009), with the front page imagery forming a "picture" in the "heads" of the readers (Lippmann 1922) regarding the days newsworthy topics. Thus, the wording of headlines, imagery used on, and layout of, the front page require careful consideration if we want to understand the message being communicated regarding topics presented on the newspaper front page and the way in which an event is framed. In terms of delivering effective text messages as headlines, a number of short-term memory recall issues are key:

- Theme-recall is better for phonemically similar lists (Wickelgren 1965); but

- Greater error will occur in retrieval of the exact words in correct order if words in a list are phonemically similar (Baddeley 1968);

- Recall will diminish with word length (Baddeley et al. 1975; Baddeley 2012); 

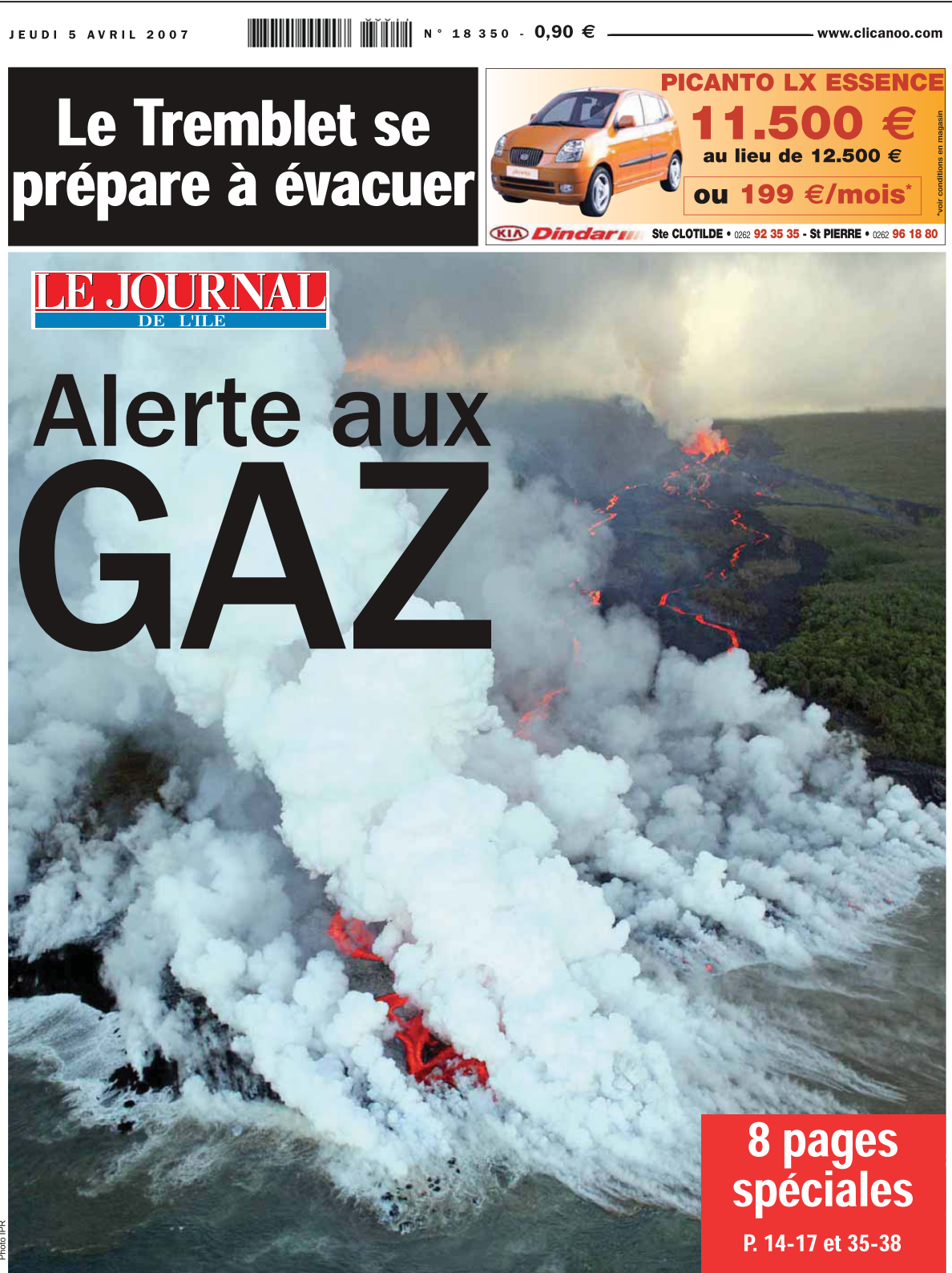

Fig. 3 Front page of JIR on 5 April 2007 ( $N^{\circ}$ 18350) three days after the eruption began and the height of gas and tephra emission

- Middle-length words are recalled worse when they are followed by long-words than when they are followed by short-words (Campoy 2008);

- Word length effects are worse for read than spoken words, and are also worse for words at the end of a list than at the beginning (Neath and Nairne 1995);

- Words at the beginning and end of a list are remembered better than words in the middle (Glanzer and Cunitz 1966)

- A familiar proverb matched with an appropriate semantic association activates memory more effectively than an unfamiliar proverb (Della Sala et al. 2010);
- Repetition and familiarity enhances ability to memorize a word list (Ebbinghaus 1885; Tulving 1985).

Baddeley et al. (1975) argued that memory span is equivalent to the number of words that can be read in two seconds, where extensive testing has proved that 7 \pm 2 "chunks" of information can be held in the shortterm memory (see Cowan (2000) for thorough review). All of this leads to the conclusion that the most effective headline delivery is achieved with a short $(7 \pm 2$ word) string of short, popular, familiar words, of interleaved middle and short length words, with the most important words appearing at the beginning and end. 
Thus, the advice in most journalism textbooks is to (i) never use a long word, when a short word will do; (ii) if it is possible to cut out a word, then cut it out; and (iii) never use foreign, scientific or jargonized words when an everyday equivalent is available (Harcup 2009). Atkinson (2011) adds two rules when writing a headline: (i) write concise sentences with a subject and a verb in active voice, and (ii) be clear, direct, specific and conversational. We see this put into play in the four headlines of Fig. 4 where the length of the headlines is $6 \pm 3$ words, word lengths are generally short, involve a mixture of short- and medium-length words which are simple and familiar, with the most important words being placed first and last in each headline. In short, the design of each slogan will maximize the chance of short-term memory storage of most of the headline.

In addition, messages are more quickly ingested if delivered in easy-to-read fonts, with display of selected words in uppercase, bold, larger size and/or color font being extremely effective in focusing the audience on the key message (e.g. Duarte 2008; Dirkson 2012; Reynolds 2014). Again, use of bold and color can be seen in setting up the headline hierarchy of Fig. 4.

It is also well-known that human-beings have a "vast memory" for pictures (Standing et al. 1972; Standing 1973), so that image-based messages can be much more memorable than texturally or verbally delivered messages (Paivio and Caspo 1973). Effective message delivery can thus be achieved through just a momentary glance at an image (Standing et al. 1972), with images containing a concealed object (or obscured object) being just as effective for mnemonic purposes as one in which all objects are pictured, although the latter is certainly a much more vivid communication means (Neisser and Kerr 1973). Use of appropriate imagery is also an effective communication device to enhance learning (Dutrow 2007). Carney and Levin (2002) thus argued that "whether ancient cave painting or computer screen icon, pictures are part of

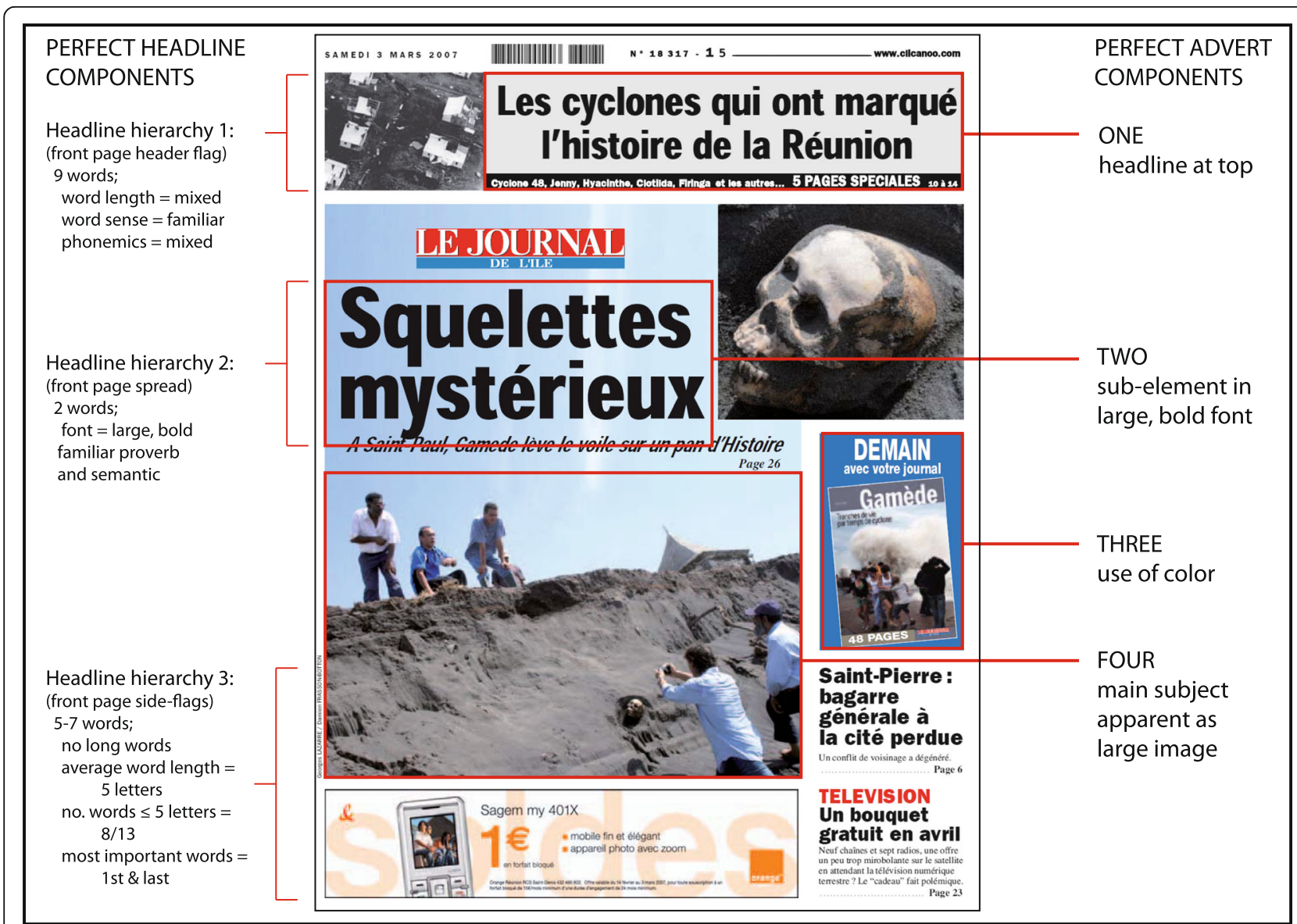

Fig. 4 Front page of JIR on 3 March 2007 ( $N^{\circ}$ 18317) illustrating the perfect format for headline writing and front page layout if recall using the short-term memory is to be maximized. The newspaper was devoted to follow-up of the passage of cyclone Gamède which passed within $250 \mathrm{~km}$ of the island of La Réunion on 24 February 2007, and then again on 27-28 February 2007; the front page header reading "The cyclones which have marked the history of La Réunion". The front page spread and imagery is devoted to the "mysterious skeletons" which were unearthed due to coastal erosion during the passage of Gamède 
the human experience," so that "carefully constructed illustrations" are "effective text adjuncts" in message delivery.

Although pictures are more memorable than words, to achieve ultimate memory recall, pictures and words should be used together (Mayer and Anderson 1992). This especially applies to those with little knowledge of the theme being delivered. Mayer and Syms (1994), for example, found that.

"Inexperienced students were better able to transfer what they had learned about a scientific system when visual and verbal explanations were presented concurrently than when visual and verbal explanations were separated."

As a result Naccarato and Neuendorf (1998) identified the four components of a "perfect" advertisement, this being a presentation format that maximizes readership information delivery, attractiveness and recall through appropriately mixing text and imagery. These four components are (Neuendorf 2002):

1. Headline placement at top;

2. Sub-elements in large, bold fonts;

3. Use of color; with

4. The subject being visually apparent.

In addition, Martin-Lagardette (2009) recommends, when considering imagery for inclusion on the front page of a newspaper, a preference for images that include faces or people. We can again see these design influences being applied in the front page example of Fig. 4. Thus, the agenda laid out in words and pictures in prominent newspaper positions will be a powerful influence in focusing public opinion on particular themes, issues or viewpoints (e.g., Katzman 1972; Morris and Peng 1994; Rowe et al. 2000). The front page design, and the frame this creates, thus needs to be considered in any content analysis aimed at understanding the effect of the news format on readership perceptions of a natural hazard.

\section{Method}

All editions of JIR published during March, April and May 2007 were checked for content regarding activity at Piton de la Fournaise. All front page articles relating to volcanic activity were then classified into one of two groups:

- Front page flags (FP-F): that is, text boxes at the top or sides of the front page pointing readers to the most newsworthy stories inside the newspaper.

- Front page spread (FP-S): this being the "story-ofthe-day" featuring a large color photograph that dominates the front page with the primary (largest

font) headline inset.

The text of all front page headlines were recorded, the type of hazard to which they referred assigned a class (following the coding system laid out in part 1), and the theme and dominant color of each image noted. The number of words in each headline, and the number of letters in each word, were also recorded, and images assigned a binary code depending on whether people or faces were present (1) or not (0). Internal articles relating to volcanic activity were processed following the methodology laid out in part 1 of this work.

We then carried out a "flash test" to assess the effect of the front page information content and design on the short term memory of the casual observer. The test followed the format of the short-term memory tests of Baddeley et al. (1975) whereby ten front pages on which the volcano and its activity was featured as the main image and headline were displayed for $1.5 \mathrm{~s}$. Between each display, subjects were given nine seconds to write down those words that entered their head, before being given a five second stop cue, and then a five second pause during which a black screen was displayed. The next page was then displayed. The second test involved the display of only the front page flags. The test was the same, except that 11 front page flags were displayed, and the subjects were given just four seconds to write down all words they could remember from the text in any sequence. Finally, as a control, a front page on which the volcano was featured only as a front page flag, and one where no volcanic information was given, were displayed. The tests were applied to three groups, two with knowledge of the volcano and its activity, and who were regular visitors to active sites, and one with no such experience. The two experienced groups were all 19 staff members (research, operations, technical, administrative and non-permanent scientific members) of the Piton de la Fournaise Volcano Observatory (OVPF), plus 52 tourist-guide professionals attending a training program for guided visits to active sites during eruptions. The inexperienced group was 24 third year geography students at l'Université de La Réunion (St. Denis). Words recorded in each test were then placed into one of three classes: impacts or volcanic processes, normal life and perturbed life.

\section{Results}

A total of 23 front page articles devoted to volcanic activity (13 front page flags and 10 front page spreads) appeared between February and May 2007, of which 16 appeared during April (Table 1). The average number of words appearing in front page headlines relating to volcanic activity was $5 \pm 2$, with a mode and median of four. This compares with $4 \pm 2$ for all front page 
Table 1 Headline analysis of front page flags (FP-F) and spreads (FP-S) relating to activity at Piton de la Fournaise during March, April and May 2007

\begin{tabular}{|c|c|c|c|c|c|}
\hline Date & Type & Text: French (with English translation) & Hazard & Text Theme & Picture Theme \\
\hline $\begin{array}{l}27 \\
\text { March }\end{array}$ & FP-F & $\begin{array}{l}\text { Volcan en vigilance et séisme à Saint-Denis } \\
\text { (Volcano under surveillance and earthquake at Saint-Denis) }\end{array}$ & Seismic & $\begin{array}{l}\text { volcano/vigilance/seismic/ } \\
\text { Saint-Denis }\end{array}$ & NO PICTURE \\
\hline $\begin{array}{l}31 \\
\text { March }\end{array}$ & FP-F & $\begin{array}{l}\text { Le Piton de la Fournaise en éruption depuis hier soir } \\
\text { (Piton de la Fournaise in eruption since yesterday evening) }\end{array}$ & Eruption & Piton/eruption/yesterday & NO PICTURE \\
\hline 1 April & FP-F & Une autre éruption en vue (Another eruption on the horizon) & Eruption & eruption & explosion/ejecta \\
\hline 3 April & FP-S & De la route à la mer (On the road to the sea) & Lava & $\mathrm{road} / \mathrm{sea}$ & $\begin{array}{l}\text { lava/responders/cameras/ } \\
\text { sightseers }\end{array}$ \\
\hline 4 April & FP-F & $\begin{array}{l}\text { NUAGE DE GAZ SUR ST-JOSEPH: Une cinquantaine } \\
\text { d'élèves intoxiqués (GAS CLOUD OVER ST-JOSEPH): } \\
\text { Around } 50 \text { students intoxicated }\end{array}$ & Gas & cloud/gas/toxic & NO PICTURE \\
\hline 4 April & FP-S & LE VOLCAN DEVIENT FOU (THE VOLCANO'S GONE MAD) & Lava & volcano/mad & lava/fire/orange/sightseer \\
\hline 5 April & FP-F & $\begin{array}{l}\text { Le Tremblet se prépare à évacuer (Le Tremblet prepares } \\
\text { to evacuate) }\end{array}$ & Evacuation & Le Tremblet/evacuate & NO PICTURE \\
\hline 5 April & FP-S & Alerte aux GAZ (GAS alert) & Gas & alert/gas & cloud/white/lava/orange \\
\hline 6 April & FP-S & Le Tremblet sous les cendres (Le Tremblet under the ash) & Ash & Le Tremblet/ash & people/cars/ash/road/umbrella \\
\hline 7 April & FP-S & Le volcan s'effondre (The volcano collapses) & Collapse & volcano/collapse & crater/grey/black \\
\hline 8 April & FP-F & Volcan à grand spectacle (The volcano big show) & Eruption & volcano/show & NO PICTURE \\
\hline 9 April & FP-F & $\begin{array}{l}\text { Sainte-Rose: de drôles de poissons repêchés au } \\
\text { large de l'éruption (Sainte-Rose: the funny fish fished } \\
\text { up at the height of the eruption) }\end{array}$ & $\begin{array}{l}\text { Ocean } \\
\text { Entry }\end{array}$ & Sainte-Rose/fish & fish/orange/bucket \\
\hline 9 April & FP-S & Le Dolomieu après le chaos (The Dolomieu after the chaos) & Collapse & Dolomieu/chaos & brown/steam/crater/ash \\
\hline 10 April & FP-F & $\begin{array}{l}\text { Le volcan livre les mystères des abysses (The volcano } \\
\text { delivers the mysteries of the deep) }\end{array}$ & $\begin{array}{l}\text { Ocean } \\
\text { Entry }\end{array}$ & volcano/mystery/abyss & lava/orange \\
\hline 11 April & FP-S & Le nouveau visage du volcan (The new face of the volcano) & Collapse & face/volcano & crater/gray/sightseer/camera \\
\hline 13 April & FP-S & Hier 15h05 (Yesterday 15h05) & Collapse & yesterday & brown/plume/volcano \\
\hline 22 April & FP-S & Les secrets de la Soufrière (The secrets of the Soufrière) & Collapse & secret/La Soufrière & grey/crater/people \\
\hline 27 April & FP-S & $\begin{array}{l}\text { La lave en route vers le Tremblet (Lava on the road } \\
\text { towards Le Tremblet) }\end{array}$ & Lava & lava/Le Tremblet & $\begin{array}{l}\text { lava/orange/road/fire engines/ } \\
\text { village }\end{array}$ \\
\hline 3 May & FP-F & $\begin{array}{l}\text { Une des plus grosses éruptions du volcan (One of the } \\
\text { biggest eruptions of the volcano) }\end{array}$ & Eruption & big/eruption/volcano & lava/orange \\
\hline 5 May & FP-F & $\begin{array}{l}\text { Quatre points de vue ouverts ce matin (Four viewing } \\
\text { points open this morning) }\end{array}$ & Eruption & four/viewing/open & lava/plume/white/black/green \\
\hline 6 May & FP-F & $\begin{array}{l}\text { Volcan: } 135 \text { euros pour avoir vu les coulées } \\
\text { de trop près! (Volcano: } 135 \text { euro to have seen the lava } \\
\text { flows close up) }\end{array}$ & Lava & volcano/135 €/view/lava & tourists/barrier/lava/black \\
\hline 13 May & FP-F & $\begin{array}{l}\text { Le sommet s'effondre à nouveau (The summit } \\
\text { collapses again) }\end{array}$ & Collapse & summit/collapse/again & $\begin{array}{l}\text { trees/brown/cone/yellow/lava/ } \\
\text { black/tourists }\end{array}$ \\
\hline 26 May & FP-F & $\begin{array}{l}\text { Coulées du Grand-Brûlé: pas de route avant août } \\
\text { (Lava flows of the Grand-Brûlé: no road before August) }\end{array}$ & Lava & $\begin{array}{l}\text { lava/Grand-Brûlé/road/ } \\
\text { August }\end{array}$ & NO PICTURE \\
\hline
\end{tabular}

headlines appearing over the 120 days of the study period, with a range of two to nine, a median of four, and a mode of three.

In terms of design, all front page formats followed the model of Fig. 4. The example of Fig. 3 illustrates adherence to this format by the newspaper on a day when the volcano featured as the front-page spread:

1. Headline placement at top reading "Le Tremblet prepares itself to evacuate", which in French is three moderate-length (7-8 letter) words separated by three short (1-2 letter) words, making it a perfectly-sized phrase for ease of recall.

2. A sub-element involving three, short, simple words (Alert to GAS) in a large, bold font, with the hazard (Gas) being capitalized.

3. Effective use of color for the main image, and a simple white font on a black background for the front page flag, plus red for the pointer to the internal page reporting; 
4. The image expressing the subject takes up $83 \%$ of the front page.

If we examine the front page examples given in Figs. 5 and 6, we see an identical design in terms of word and imagery use and layout. Given the recommendation of Martin-Lagardette (2009) regarding inclusion of people or faces in front page images, we also checked all front-page spread images for such a preference. Of 117 front pages examined over the four month study period, a face or a person featured in 91 of them. That is, $78 \%$ of the front pages featured a person carrying out an action.
When associated with hazardous situations this involved firemen, policemen, civil protection officials or coastguards; meaning that in each case a responder was pictured protecting structures, responding to crime, assessing a hazard, or rescuing people. Note, for example, that the main images of Figs. 5 and 7 include people, with Fig. 5 including a policeman (Gendarmerie)-even if he is in the second row and taking a photograph.

What volcanic hazards did the front page focus on? By number of front pages carrying volcanic hazard as the main theme, the collapse events of the Cratère Dolomieu

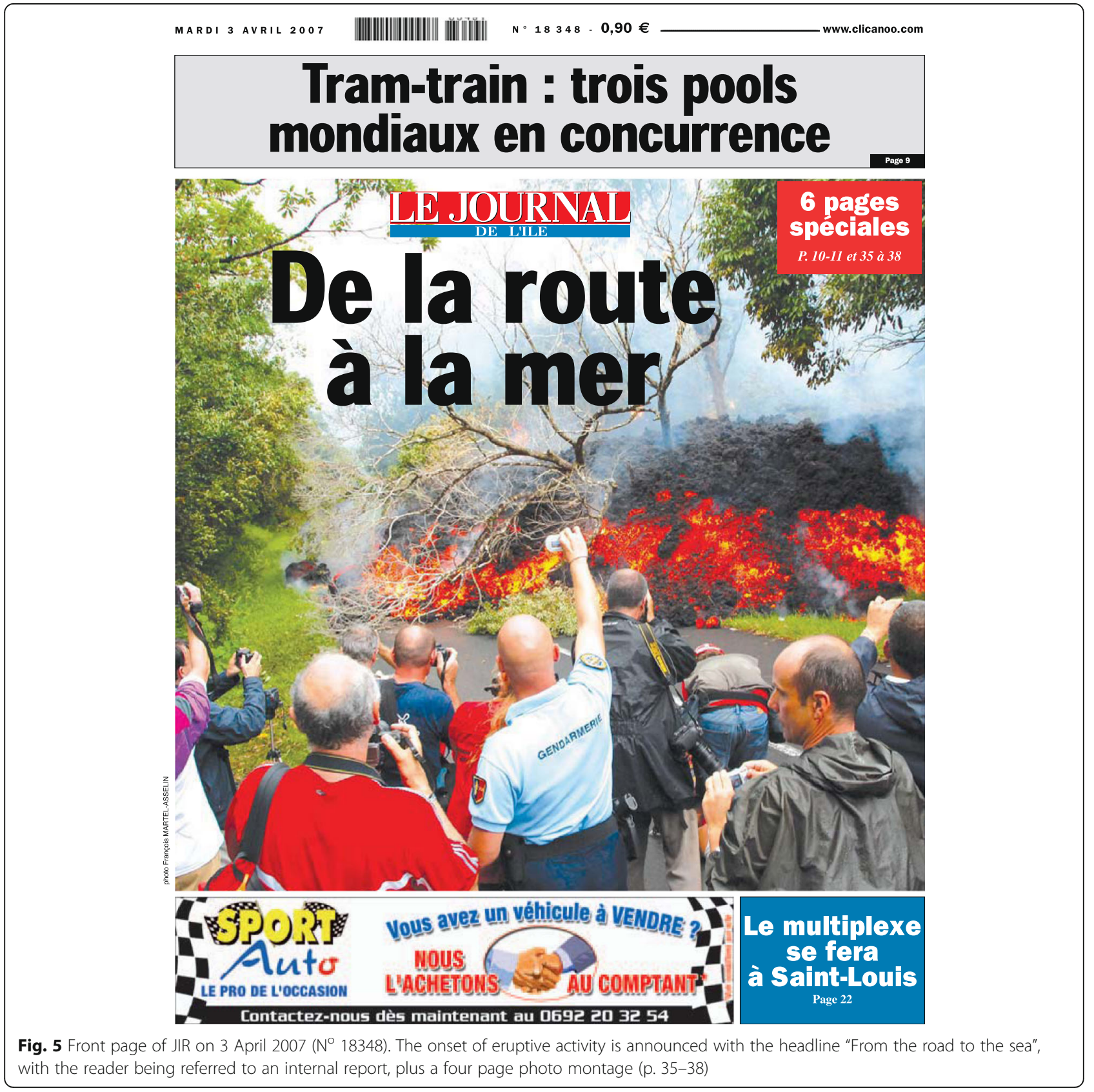




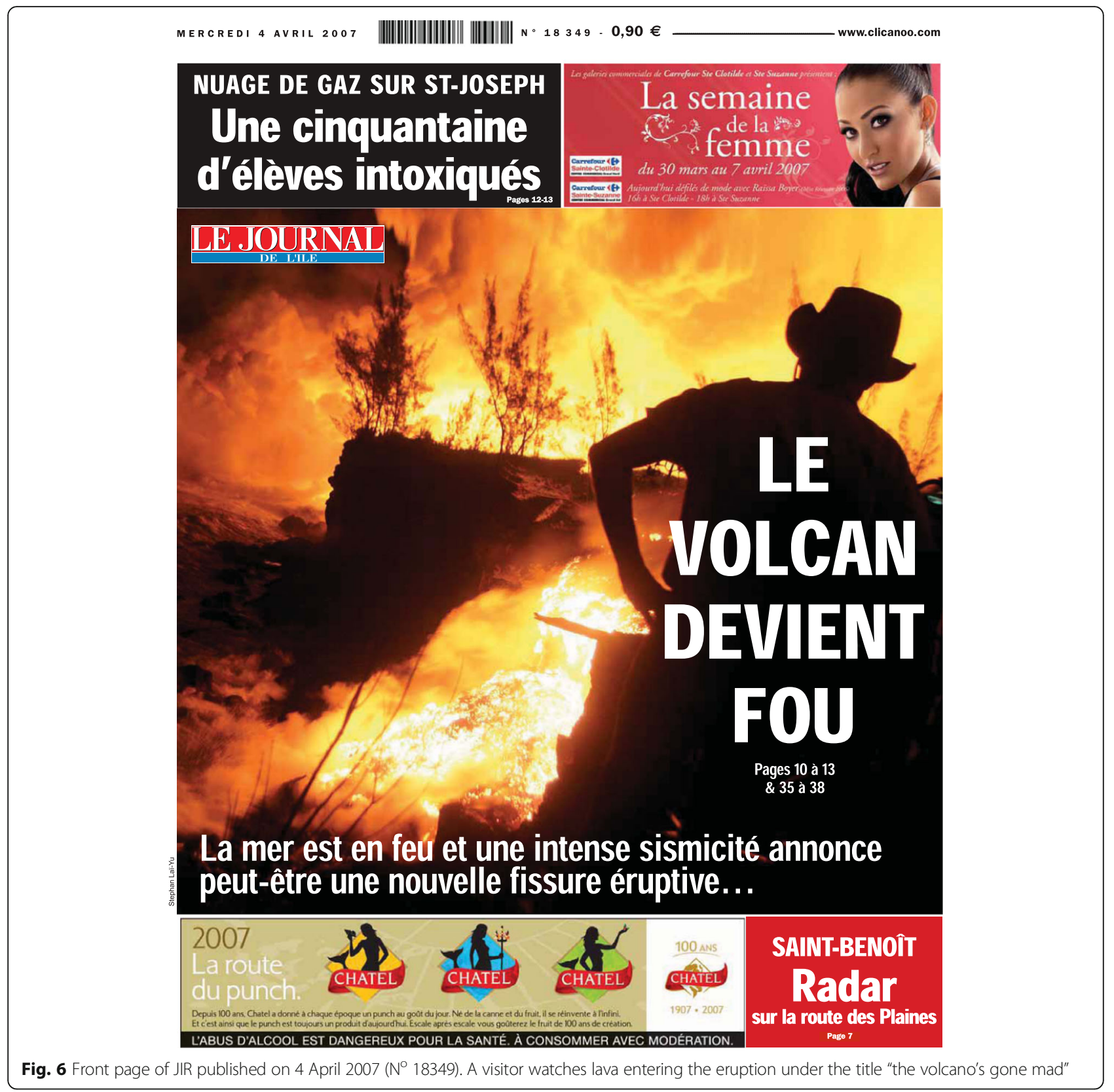

featured most highly, being the main theme of six of the front page articles. Next was lava (five front page appearances), followed by gas and ocean entry hazards (two appearances), with seismic, ash and evacuation themes featuring on the front page just once (Table 1). However, if we complete a word count on all words appearing in all front page headlines of Table 1, we instead have the following ranking:

1. Volcano (eight occurrences);

2. Eruption (four occurrences);

3. Le Tremblet (three occurrences);

4. Road (three occurrences).
Thus, in terms of word repetition, the material damage (to the road) caused by lava ingress and the need for evacuation (of Le Tremblet) were the most important issues. These were texturally linked with the generic hazard due to the volcano or the eruption, rather than specific hazards such as lava flow, air fall or gas. In terms of individual hazard, lava + flow was the most frequently used (three occurrences), followed by gas and collapse (both with two occurrences), and then seismic, ash and sea each with one occurrence.

In terms of the dominant theme of the front page, this began with lava and the crossing of the road and ocean 

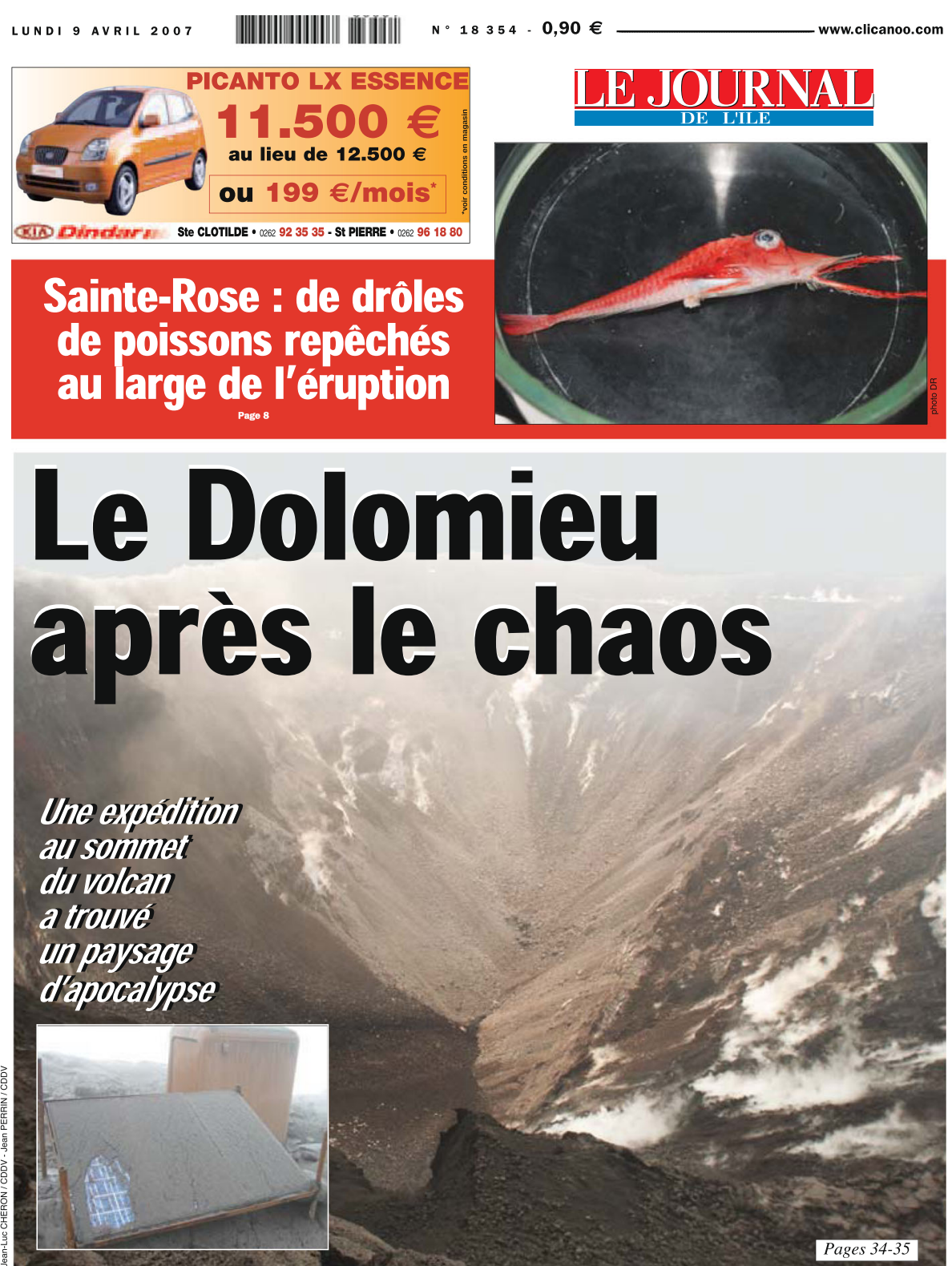

Fig. 7 Front page of JIR on 9 April ( $N^{\circ}$ 18854) featuring the collapse of the Cratère Dolomieu under the title "The Dolomieu after the chaos". This was also the first time (in 2007) that the Ocean Entry made the front page, and is apparent as a front page flag entitled "Sainte-Rose: funny fish fished-up at the height of the eruption"

entry on 3 and 4 April, respectively. Focus then switched to gas and air fall on 5 and 6 April, respectively, before becoming entirely focused on the collapse of the Dolomieu (on 7, 9, 11, 13 and 22 April). This was in spite of the fact that the main collapse occurred on 67 April, but ocean entry and lava flow continued throughout the eruption. The threat of lava flow invasion to Le Tremblet only became a focus again on the final front page that featured the eruption, that of 27 April, when the eruption had more-or-less ended. Thus, the reporting of hazard followed the primary activity type until 7 April, when the focus became distracted by the collapse of the Dolomieu; the "hazardof-the-day" being demoted to an (often-poorly framed) front page flag (e.g., Fig. 7).

\section{Words and images}

In terms of the words and imagery associated with the eruption we find the following commonalities:

- Lava was associated with the color orange during the eruption, and black after it; the collapse was 
framed in gray and the gas plume in white (c.f.

Figs. 3, 5 and 7);

- With one exception, people were always pictured taking photographs. Note that all 11 people in the front page image of Fig. 5 are taking a picture; as already noted this even includes the responder-even the scientist-in-charge of OVPF was pictured taking a picture when he appeared in the front page image of 11 April 2007;

- With one exception, people appearing in eruption imagery were always sightseers and tourists (e.g., Fig. 6);

- Words and pictures associated with ocean effects focused on "fish", "mystery" and the "abyss", with the ocean entry being framed in such a way three times on the front page as a flag (Table 1). A good example of this frame is the example of Fig. 7, which frames the ocean effects with a picture of a dead exotic-looking fish against a neutral background which, although being the bottom of a sample beaker, has a first-glance resemblance of a frying pan;

- Keywords used changed in time from

$\circ$ "vigilance" through

o "toxic", "mad", "evacuate", "alert" and "chaos", to

○ "show", "mystery", "new face", "secret", "open" and "view".

The event-frame thus evolved from one of alert to one of show; attracting sightseers who took photographs from a close distance, with the time-frame invariably being "yesterday" (Table 1).

\section{Flash tests}

Results of our content analysis were borne out by those of the flash tests. Flash tests completed using the front pages revealed that imagery and headline words used reflected the range of hazards quite evenly, with all hazards being amongst the top ten most frequent responses for all groups (Fig. 8). In fact, we see that the distributions of Fig. 8 are consistent with the top three words recorded from the front page tests being the same for each group. These were:

1. Volcano (accounting for $9-10 \%$ of all words recorded in all three cases);

2. Collapse (5-6\%); and

3. Lava (4-6\%).

After that, all other words recorded were the samewith the exception of "fumes", which was only recorded by the student group. Interestingly, the OVPF and guide groups both had "Dolomieu" and "flow" as the 4th and 5th most commonly recorded words, whereas the student group had "road" and "fumes". This no doubt reflects better familiarity with the volcano and its products amongst the former two groups than the latter, with fumes being the association of the students with the plume.

The OVPF staff, guide and student groups respectively used 235, 251 and 216 different words to describe the ten front pages displayed. However, imagery and headline words failed to conjure up feelings of risk, hazard or loss, instead they evoked reactions such as "red", "hat", "sea", "bus stop", "new" and "face", the only hazard-relevant word recorded being "chaos" (Table 2). In the case of "hat", this was due to the silhouette of a sightseer being prominent on the front page of the 4 April edition of JIR (Fig. 6).

For the flash tests completed for the front page flags, all three groups retained $3 \pm 1$ words, and all three groups recorded 56 different words. There was a weak positive correlation $\left(R^{2}=0.6\right)$ between the number of words in the text and the number of different words returned by all participants. All words in the text were returned only for cases less than six words in length. We recorded retention of hazard and risk words in the first three cases (Table 3); thereafter words such as "show", "fish", "mystery", "open" and "view" dominated. When, given the front page of 31 March (Fig. 2), no respondent noticed that the eruption had begun-as announced by a front page flag in the topleft corner of the page.

If we examine the class of word retained from flash test results for both the headline and front page flag, we find that the statistics are again identical for all three groups (Fig. 9). Although words associated with volcanic hazards represented up to $60 \%$ of the words by type; typically less than $11 \%$ were words associated with a perturbed life. In fact, for the text boxes, around $60 \%$ of the words were associated with a normal life (Fig. 9). Hence, the perception of the event was not one of alarm, but instead the imagery and text used framed the event as non-risky and safe; even approachable and exciting.

\section{Discussion}

Because of the excellent design of the front page of JIR in terms of maximizing information delivery to the shortterm memory, it is important to understand what message was likely received by the readership and how that framed each volcanic process and its associated hazard. We here discuss what that message was, and search reports deeper in the newspaper to understand if this message was supported by the detailed reporting within the body of the newspaper. We then finish by exploring what were the effective elements of the framing process, so as to provide guidelines as to how the volcanologist can define, track and respond to frames in the mass media.

\section{The frames}

Our content analysis shows that only the well-known (pit crater and lava flow) hazards were framed in a way 

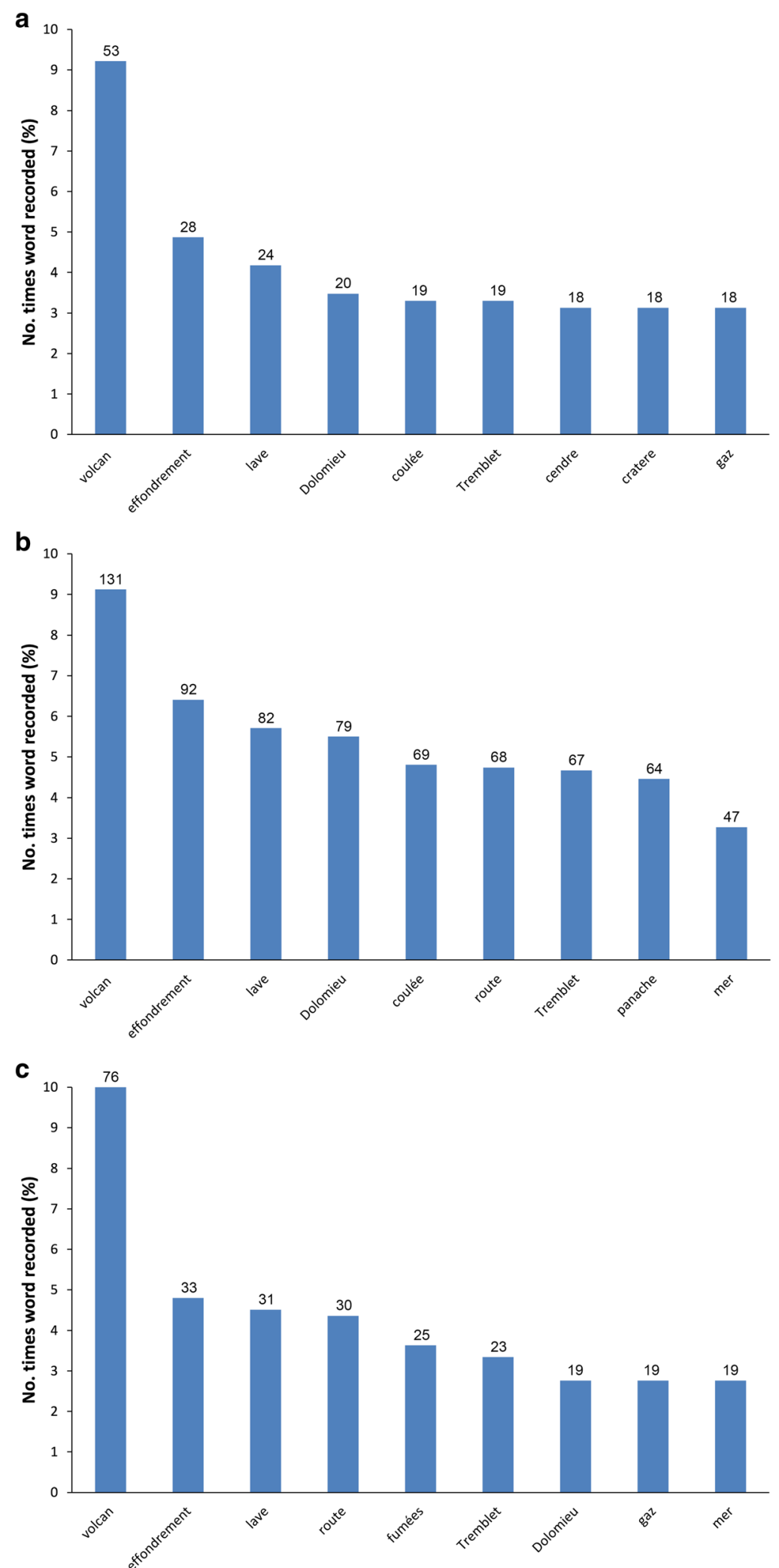

Fig. 8 (See legend on next page.) 
(See figure on previous page.)

Fig. 8 Top ten words recorded across all ten front page tests by (a) the OVPF group, (b) the guide group and (c) the student group. Results are given as percentages of the total number of words recorded, this being 575, 1436 and 688 for the three groups, respectively. Actual number of times each word was recorded is given at the head of each bar. Original language is used (i.e. actual words shown) where these are: volcan $=$ volcano; effondrement = collapse; lave = lava; coulee = flow; cendre = ash; cratere = crater; gaz = gas; route = road; panache = plume; mer = ocean; fumes $=$ fumes

that provided effective hazard communication that could achieve the disaster managers goal, that being to educate the population through reporting in the mass media (e.g., Coppola 2015). Instead, gas, air fall and ocean entry hazards, as well as evacuation plans and the functioning of decision making system were poorly framed, thereby failing as an educative measure. Instead, they served to further engender a frame of entertainment, uncertainty, fear, panic and failure.

\section{The pit-crater collapse frame}

The front page representation of pit-crater collapse is well-expressed by the JIR front page spread of 9 April 2007 (Fig. 7). Here we see a sober, daytime image of the summit pit resulting from the 8 April collapse overlain with a headline comprising five, short words: "The Dolomieu after the chaos". Here, the word "chaos" is used for "collapse", with collapse being used in all later headlines. The four other front page spreads pertaining to summit collapse were equally sober:
1. That of 7 April 2007 (Fig. 10a) was entitled "the volcano collapses"; featuring an image of the crater (Table 1), that was recalled as "volcano", "collapse" and "crater" by the flash tests (Table 2).

2. That of 11 April 2007 (Fig. 10b) was entitled "the new face of the volcano"; it featured a man taking a picture of the crater (Table 1), who four members of the OVPF staff recognized as being Thomas Staudacher (Table 2), the director of OVPF at the time of the eruption.

3. That of 13 April 2007 (Fig. 10c) was simply labeled "yesterday 15h05"; giving an image of the brown plume resulting from the collapse (Table 1), that was recalled as "cinder", "plume" and "yesterday" by the flash tests (Table 2).

4. The front page spread of 22 April 2007 led of the Sunday edition of the JIR (Fig. 10d) and, being the advertisement for a review piece on "seven special pages" devoted to pit crater formation at the Cratère Dolomieu was evocatively entitled "the secrets of La Soufrière."

Table 2 Results of front page flash tests, giving the number of words recorded by the OVPF group

\begin{tabular}{|c|c|c|c|c|c|c|c|}
\hline Run & Date & $\begin{array}{l}\text { Headline (see Table } 1 \text { for translation } \\
\text { of headlines) }\end{array}$ & Theme & Average & No. & No Diff & $\begin{array}{l}\text { Responses with frequency }>3 \\
\text { (English translation in parentheses) }\end{array}$ \\
\hline 1 & $03 / 04 / 2007$ & De la route à la mer (Fig. 5) & Lava & $3.4 \pm 1.3$ & 62 & 26 & $\begin{array}{l}\text { route (9); lave (7); volcan (7); mer (4); rouge (4) } \\
\text { (road, lava, volcano, sea, red) }\end{array}$ \\
\hline 2 & 04/04/2007 & LE VOLCAN DEVIENT FOU (Fig. 6) & Lava & $3.5 \pm 1.1$ & 62 & 25 & $\begin{array}{l}\text { volcan (11); chapeau (7); feu (6); fou (5); nuit (5); } \\
\text { rouge (4) (volcano, hat, fire, mad, night, red) }\end{array}$ \\
\hline 3 & 05/04/2007 & Alerte aux GAZ (Fig. 3) & Gas & $3.6 \pm 0.9$ & 65 & 25 & $\begin{array}{l}\text { gaz (14); mer (11); fumée (6); alerte (4); coulée (4); } \\
\text { volcan (4) (gas, sea, smoking, alert, flow, volcano) }\end{array}$ \\
\hline 4 & 06/04/2007 & Le Tremblet sous les cendres (Fig. 12) & Ash & $2.9 \pm 1.3$ & 55 & 23 & $\begin{array}{l}\text { cendres (10); Tremblet (9); parapluie (6); } \\
\text { Bus + arête (4) (ash, Tremblet (the village of), } \\
\text { umbrella, bus + stop) }\end{array}$ \\
\hline 5 & 07/04/2007 & Le volcan s'effondre (Fig. 9a) & Collapse & $3.1 \pm 1.0$ & 56 & 20 & $\begin{array}{l}\text { effondrement (14); volcan (10); cratère (4); } \\
\text { Dolomieu (4) (collapse, volcano, crater, } \\
\text { Dolomieu-the crater of) }\end{array}$ \\
\hline 6 & 09/04/2007 & Le Dolomieu après le chaos (Fig. 7) & Collapse & $2.9 \pm 1.3$ & 54 & 22 & $\begin{array}{l}\text { Dolomieu (12); chaos (7); après (4); cratère (4); } \\
\text { effondrement (4) (Dolomieu, chaos, after, } \\
\text { crater, collapse) }\end{array}$ \\
\hline 7 & $11 / 04 / 2007$ & Le nouveau visage du volcan (Fig. 10b) & Collapse & $3.3 \pm 1.2$ & 59 & 24 & $\begin{array}{l}\text { cratère (7); volcan (7); nouveau (5); visage (5); } \\
\text { Thomas Staudacher (4) (crater, volcano, new, } \\
\text { face, Thomas Staudacher-Scientist-In-Charge } \\
\text { of OVPF) }\end{array}$ \\
\hline 8 & 13/04/2007 & Hier 15 h05 (Fig. 10c) & Collapse & $3.3 \pm 0.9$ & 56 & 24 & $\begin{array}{l}\text { volcan (9); panache (7); cendre (6); hier (6) } \\
\text { (volcano, plume, ash, yesterday) }\end{array}$ \\
\hline 9 & $22 / 04 / 2007$ & Les secrets de la Soufrière (Fig. 10d) & Collapse & $3.1 \pm 1.3$ & 56 & 25 & Soufrière (11); secret (4) (Soufrière, secret) \\
\hline 10 & $27 / 04 / 2007$ & La lave en route vers le Tremblet (Fig. 11) & Lava & $3.4 \pm 1.3$ & 61 & 20 & $\begin{array}{l}\text { lave (12); Tremblet (10); coulée (9); route (6); } \\
\text { rouge (4) (lava, Tremblet (the village of), } \\
\text { flow, road, red) }\end{array}$ \\
\hline
\end{tabular}


Table 3 Results of front page flag flash tests, giving the number of words recorded by the OVPF group. See Table 1 for translation of headlines

\begin{tabular}{|c|c|c|c|c|c|c|c|}
\hline Run & Date & Headline & Theme & Average & No. Words & No Diff & $\begin{array}{l}\text { Responses with frequency }>3 \\
\text { (English translation in parentheses) }\end{array}$ \\
\hline 1 & $27 / 03 / 2007$ & $\begin{array}{l}\text { Volcan en vigilance et séisme à } \\
\text { Saint-Denis }\end{array}$ & Earthquake & $2.7 \pm 1.0$ & 8 & 48 & $\begin{array}{l}\text { volcan (15); vigilance (14); séisme (7) } \\
\text { (volcano, watch (as in hurricane watch, } \\
\text { for example), earthquake) }\end{array}$ \\
\hline 2 & $04 / 04 / 2007$ & $\begin{array}{l}\text { NUAGE DE GAZ SUR ST-JOSEPH: } \\
\text { Une cinquantaine d'élèves intoxiqués }\end{array}$ & Gas & $2.4 \pm 0.6$ & 10 & 43 & $\begin{array}{l}\text { cinquantaine (11); élèves (8); intoxiqué (7); } \\
\text { gaz (4) (around 50, pupils, intoxicated, gas) }\end{array}$ \\
\hline 3 & $05 / 04 / 2007$ & Le Tremblet se prépare à évacuer & Evacuation & $2.7 \pm 0.8$ & 6 & 49 & $\begin{array}{l}\text { Tremblet (17); évacuation (13); prépare (9) } \\
\text { (Tremblet-the village of, evacuation, perpares) }\end{array}$ \\
\hline 4 & 08/04/2007 & Volcan à grand spectacle & Eruption & $2.6 \pm 0.7$ & 4 & 46 & $\begin{array}{l}\text { Grand (10); spectacle (16); volcan (16) (Big, } \\
\text { show, volcano) }\end{array}$ \\
\hline 5 & 09/04/2007 & $\begin{array}{l}\text { Sainte-Rose: de drôles de poissons } \\
\text { repêchés au large de l'éruption }\end{array}$ & Ocean Entry & $2.9 \pm 0.8$ & 10 & 52 & $\begin{array}{l}\text { poisson (12); St. Rose (12) drôle (6) (Fish, St. } \\
\text { Rose-the town of, funny) }\end{array}$ \\
\hline 6 & $10 / 04 / 2007$ & $\begin{array}{l}\text { Le volcan livre les mystères des } \\
\text { abysses }\end{array}$ & Ocean Entry & $2.6 \pm 0.6$ & 7 & 46 & $\begin{array}{l}\text { volcan (17); mystère (10); livre (8); abysses (7) } \\
\text { (Volcano, mystery, delivers, abyss) }\end{array}$ \\
\hline 7 & 03/05/2007 & $\begin{array}{l}\text { Une des plus grosses éruptions } \\
\text { du volcan }\end{array}$ & Eruption & $2.7 \pm 1.0$ & 7 & 49 & $\begin{array}{l}\text { grosse (15); éruption (12) plus (6); volcan (5) } \\
\text { (big, eruption, prefix for the biggest (plus } \\
\text { grosse = the biggest), volcano) }\end{array}$ \\
\hline 8 & 05/05/2007 & $\begin{array}{l}\text { Quatre points de vue ouverts } \\
\text { ce matin }\end{array}$ & Eruption & $3.1 \pm 1.6$ & 7 & 56 & $\begin{array}{l}\text { ouvert (12); point (11); quatre (8); vue (8); } \\
\text { matin (5) (open, point, four, view, morning) }\end{array}$ \\
\hline 9 & 06/05/2007 & $\begin{array}{l}\text { Volcan: } 135 \text { euros pour avoir vu } \\
\text { les coulées de trop près! }\end{array}$ & Lava & $2.9 \pm 0.9$ & 11 & 53 & $\begin{array}{l}135 \text { (16); } €(14) \text {; volcan (8); près (6); coulée (4) } \\
(135, \text { volcano, near, lava) }\end{array}$ \\
\hline 10 & $13 / 05 / 2007$ & Le sommet s'effondre à nouveau & collapse & $2.3 \pm 0.7$ & 5 & 42 & $\begin{array}{l}\text { effondre (13); sommet (13); nouveau (9) } \\
\text { (collapse, summit, new) }\end{array}$ \\
\hline 11 & $26 / 05 / 2007$ & $\begin{array}{l}\text { Coulées du Grand-Brûlé: pas de } \\
\text { route avant août }\end{array}$ & Lava & $2.7 \pm 1.0$ & 9 & 48 & $\begin{array}{l}\text { coulée (10); Brulée (9); Grande (8); route (7); } \\
\text { aout (5); pas (4) (flow, burnt-although this is } \\
\text { associated with the place name, Le Grande } \\
\text { Breulée ... hence the next word-Grande, road, } \\
\text { August, not). }\end{array}$ \\
\hline
\end{tabular}

People were rarely included in imagery of summit collapse, with a person appearing in only one of the four front-page spread images that appeared during April 2007.

In terms of internal reporting, the risk of crater rim instabilities and collapse was well-known, having already been stressed in a 29 March 2007 report by Martel-Asselin (2007a). On 4 April, a page 11 report focused on the potential of summit collapse, quoting OVPF staff as saying "the earthquakes are probably precursory signs of a collapse beneath the summit zone" (Martel-Asselin 2007b). Thus, this was a relatively well-known hazard and an event for which the readership was well prepared.

However, possibly because of the distance of Cratère Dolomieu's summit from populated areas and because the crater area is a major tourist attraction, the pitcrater collapse itself was treated with curiosity and interest. For example, on 11 April a two page report (spanning pages 12 and 13 of JIR) documented the history of the Cratère Dolomieu's many collapses. Under the title "The 100 faces of Piton de la Fournaise" the article began by arguing (Dupuis and Martel-Asselin 2007):

"If Piton de la Fournaise could talk, he would amuse and probably astonish the followers of his events. The only ones to have been taken by surprise by the summit collapse which began on Friday are the scientists."

However, this frame changed for the second collapse event. Instead this event was described as a "menace", being announced with the page 10 headline,

\section{ATTENTION, DANGER! \\ The Bory Crater takes his turn to threaten.}

Collapses also became associated with ash plume hazard, with VAAC and Metéo France air-space warnings being reported after both the 3 and 12 April collapses. On 17 April, text on page 4 read,

"The greatest caution must be taken when flying over the volcano and lava flows in light aircraft; some have suffered damage related to dust emission or unpredictable turbulence".

The article added that the ash was a risk for helicopter engines, and turbulence was of particular concern for the "most sensitive" craft. Here there is a dichotomy in the 


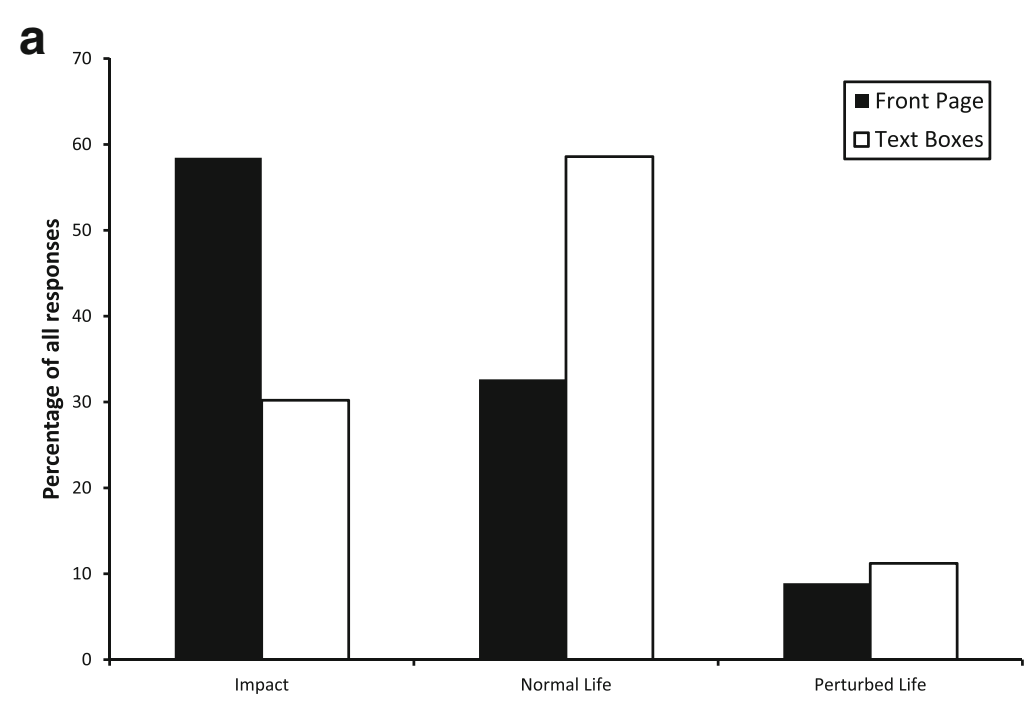

\section{b}
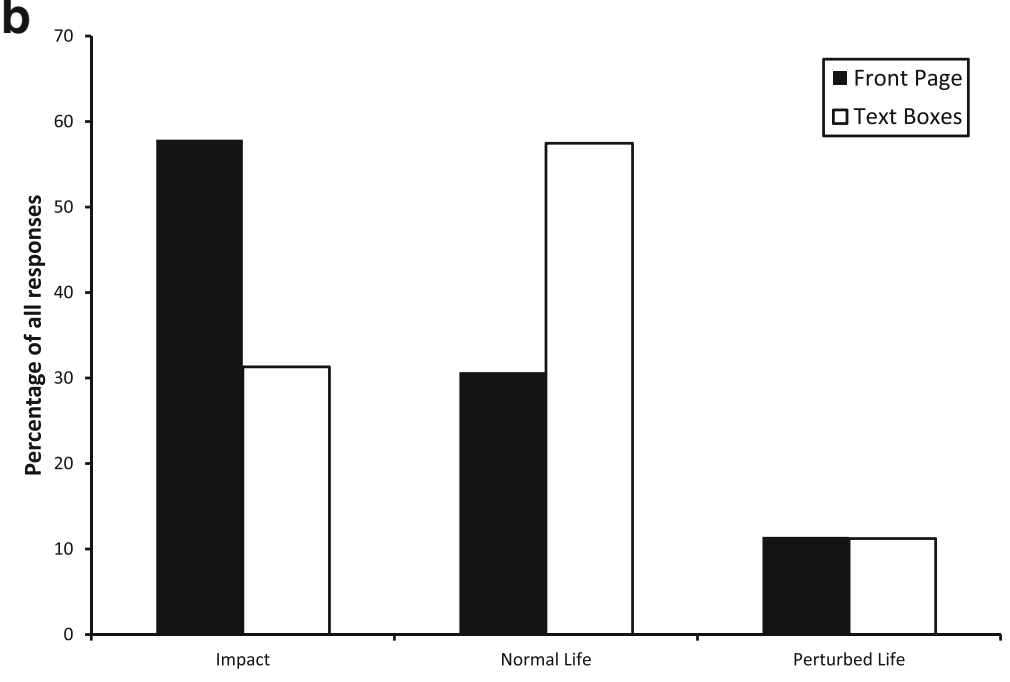

C

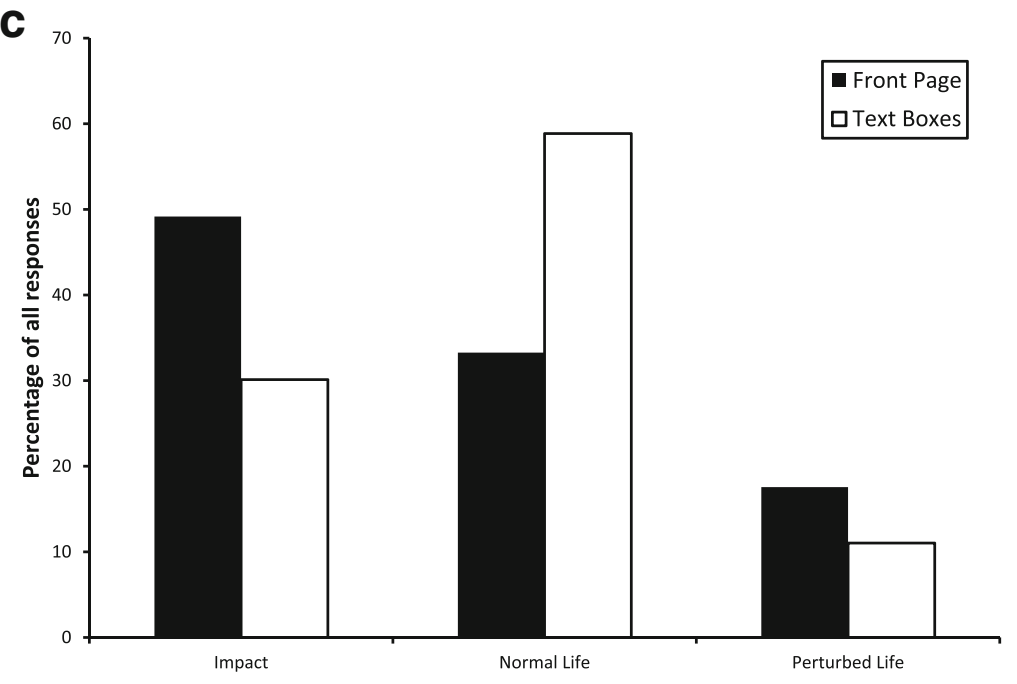

Fig. 9 Placement of all words returned for the front page and front page flag tests into one of three classes (impacts or volcanic processes, normal life and perturbed life) for (a) the OVPF group, (b) the guide group and (c) the student group 
a
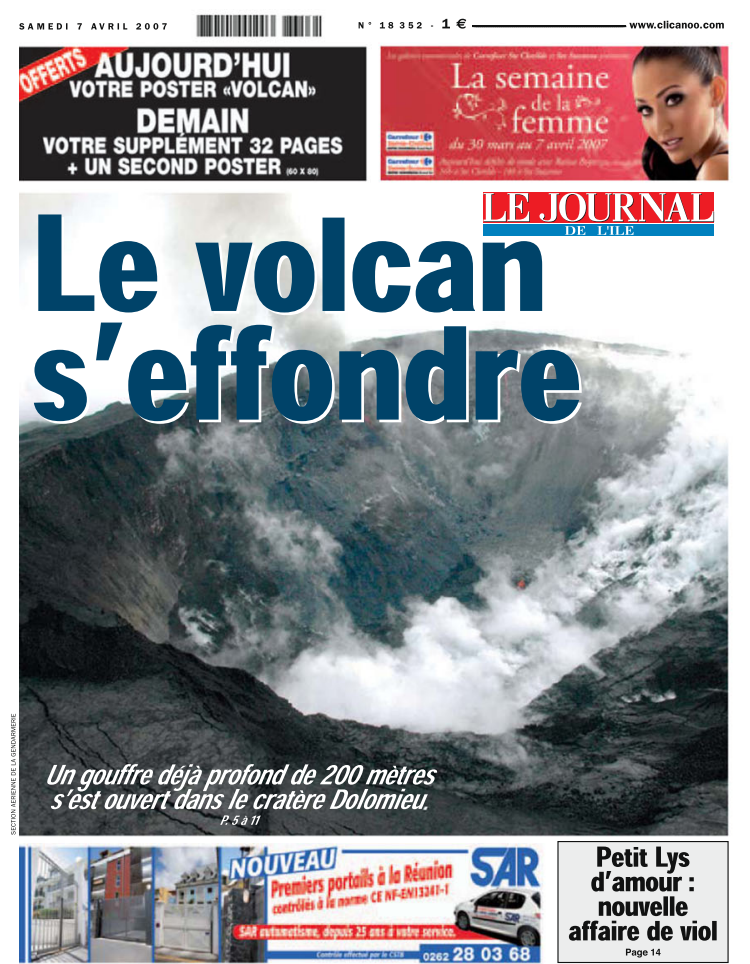

b
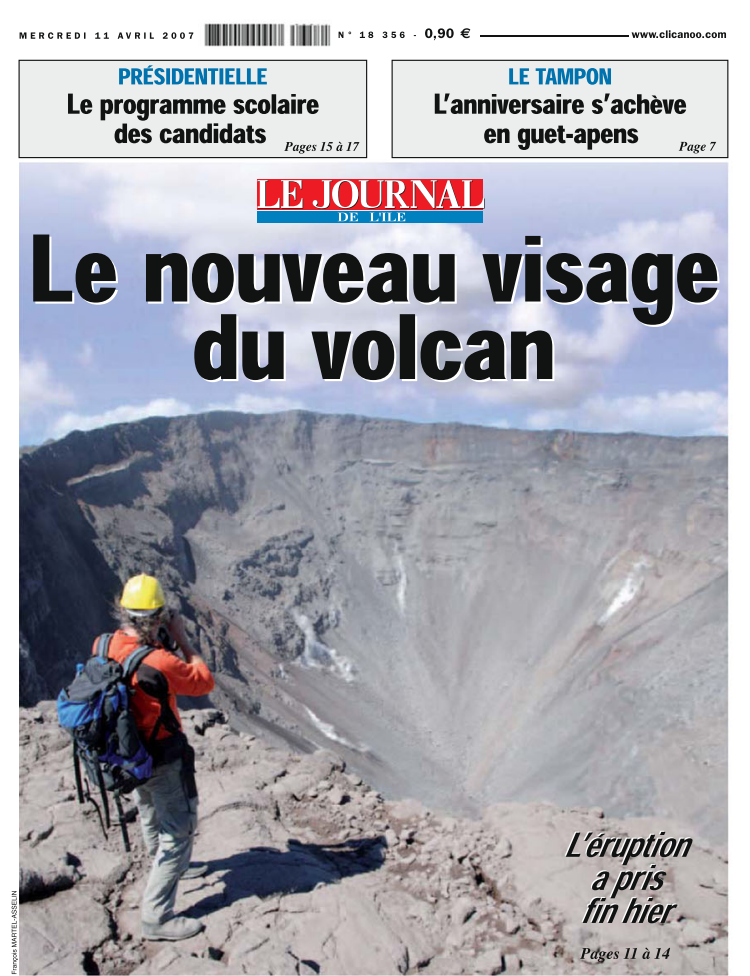

C

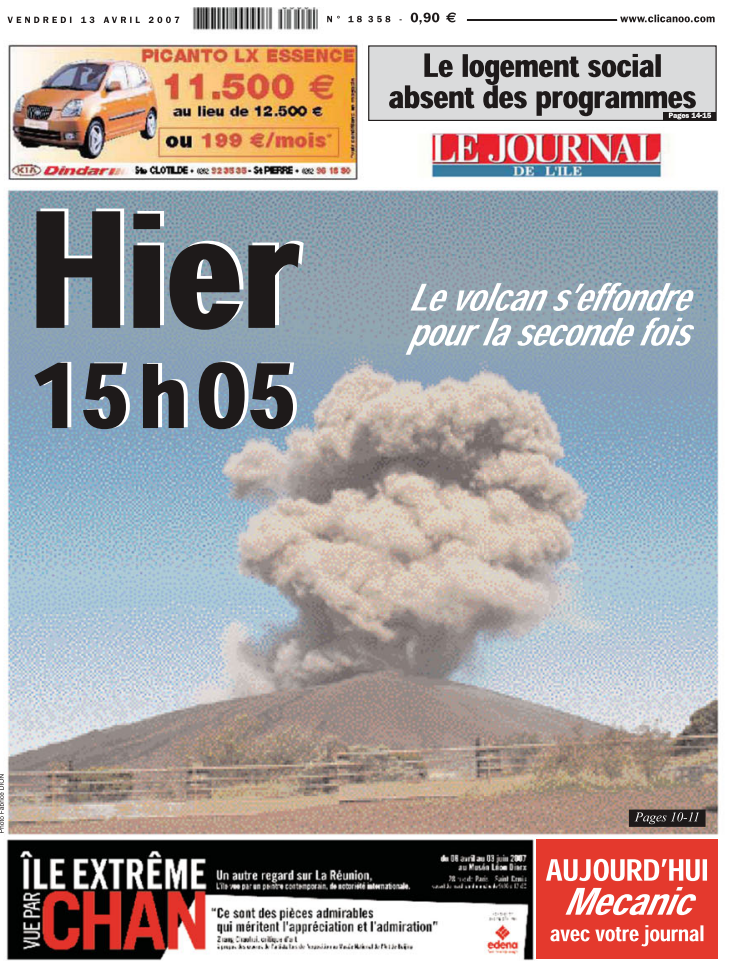

d
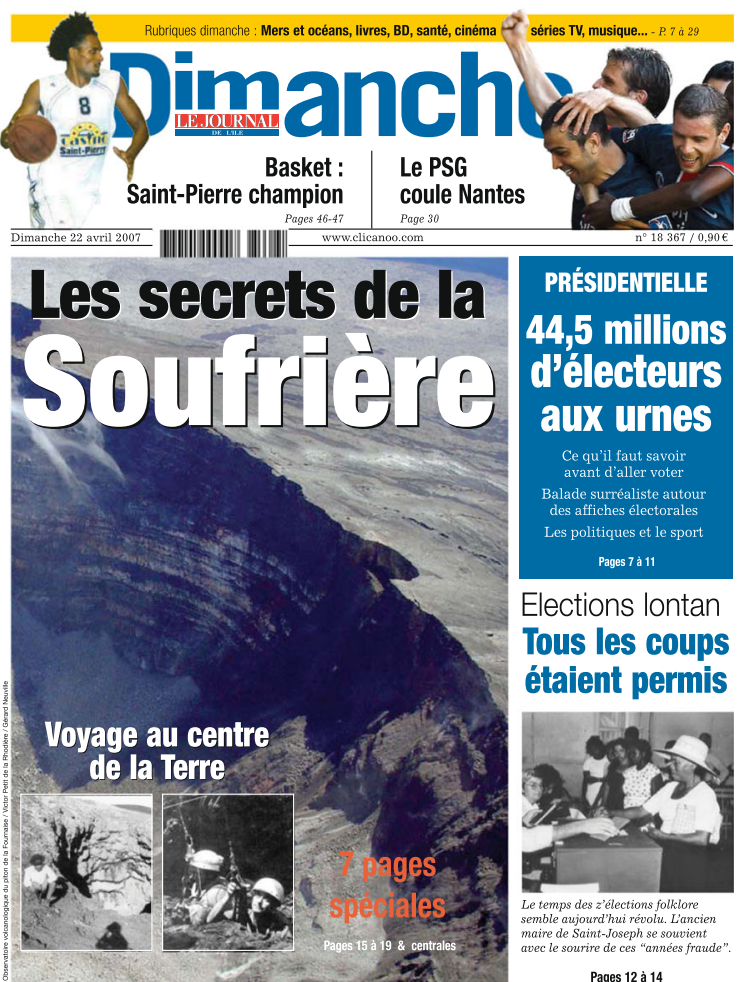

PRÉSIDENTIELLLE

44.5 millions

d'électeurs

aux urnes

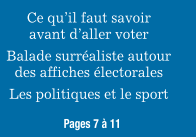

Elections lontan

Tous les coups étaient permis

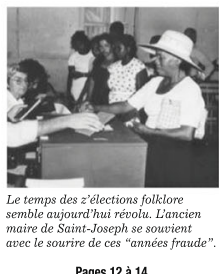

Fig. 10 Front pages of JIR featuring pit-crater collapse published on (a) 7 April 2007 ( $N^{\circ}$ 18352), (b) 11 April 2007 ( $\left.N^{\circ} 18356\right)$, (c) 13 April 2007 ( $N^{\circ}$ 18358), and (d) 22 April 2007 ( $\left.N^{\circ} 18367\right)$ 
framing of the risk, as on the same day an advert appeared in the Agenda section (page 59) of the paper reading:

\section{Survol du Piton de la Fournaise St-Paul}

Overfly Piton de la Fournaise from the ultra-light base of Cambaie.

Special rate of 145 euros during the duration of the eruption for a return trip direct to the volcano! Information and reservations:

Agency and telephone number redacted.

Supported by a photograph of a vent feeding an extensive, braided, lava channel system the advert ran for four consecutive days. Previously, on 12 April, a full page article had appeared on page 9 of JIR featuring the ultralight flight industry for volcano tourism and over flights. Thus, although the readership was well and soberly informed on the hazard, there was still an element of tourism and sightseeing to the frame.

\section{The lava frame}

The lava frame was dominated by spectacular photos of incandescent fountains feeding lava channels, flow fronts and ocean-entry flows (e.g., Fig. 6). The lava tended to dominate the photo montages and front page flags, and was associated with tourism and photography, the problems caused to the local population being of secondary importance. These lava flows were thus portrayed as an attraction rather than a threat. For example, on 3 April the three-page photo montage (JIR, 3 April 2007, pages 36-38) was dominated by spectacular color images of incandescent lava channels and ocean-entry lava surrounded by sightseers, as was the front page (Fig. 3). Hence our flash tests returned memories of images such as a tourist's "hat" and the color "red" (Table 2). It was only late in the eruption that the front-page frame for lava became less voyeuristic, with the front page of 27 April featuring an image of lava flows moving up the road into Le Tremblet, with emergency services at-hand for forest fire damp down, under the headline Lava on the road towards Le Tremblet (Fig. 11).

Deeper in the newspaper, the lava hazard was communicated in text through description and analogy to previous events that had impacted populations on La Réunion. For example, in the precursory phase of reporting, the readership had been reminded of the recent evacuations and damage inflicted on populated areas in 1977, 1986 and 2002 (Martel-Asselin 2007c). The experience of lava invasion of Sainte-Philippe in 1986 was also still fresh in the memory of the local population as revealed by witness statements. For example, on 6 April the experience of 1986 was mentioned directly five times in one article alone (Leyral 2007). This article appeared with a photo captioned,
"The memories of the 1986 lava flow remain in all of our spirits, from the youngest to the oldest one is worried about a new eruption outside of 'L'Enclos'."

In addition, a four-page-long review of the 1977 eruption and invasion of Piton Sainte-Rose appeared in the Sunday Magazine supplement of 8 April (JIR, 8 April 2007, pages 14-17). However, the problems caused due to the closure of the island perimeter road (RN2) due to lava inundation was reduced to a small $\left(280 \mathrm{~cm}^{2}\right)$ report in the bottom left corner of page 13 (JIR, 8 April 2007); and after the end of the eruption, issues regarding tourist access and sightseeing dominated reports. Thus, the lava frame was one of colorful spectacle and sightseeing on the front page, with the hazards being spelled out using text-only on deeper pages.

\section{The gas frame}

The gas problem tended to be pictured in black and white, with images featuring people and faces rather than the hazard itself (e.g., Fig. 12). These people were the victims of gas, such as school children and the responders attending to the victims, mainly fire and medical staff. Unlike the lava frame, no preparatory, background or anecdotal information was given regarding the gas hazard. Explanations of the problem only appeared the day after the gas made a first impact (Leyral 2007a), and it was not until two days following the initial reporting of the gas hazard, on 5 April, that this hazard was featured on page 1 , appearing under headline "GAS alert" and featuring a heavily condensed, billowing plume (Fig. 3). There was also no community memory of such impacts, as revealed from the following passage in Leyral (2007b),

"From the youngest to the oldest (people), it is unbelief that dominates. 'We have never seen that', is the phrase invariably repeated by the people one meets in the main street."

As a result, the gas hazard was an unknown threat, and became associated with words such as "fear", "panic", "worried" and "catastrophe", all of which appear in the report of Fig. 12. This 4 April report, appearing under the page 12 headline, "A cloud of sulfur causes a wind of panic", lead off with a paragraph that read (Leyral 2007b),

"Around fifty adolescents affected, fourteen taken to the hospitals of Saint-Joseph and Saint-Pierre. This is the social consequence of the passage of a cloud of volcanic gases through the town center of SaintJoseph early yesterday afternoon. Fortunately causing more fear than harm."

Experience was thus a key factor controlling appropriate reporting and conveying of the gas hazard. That is, 


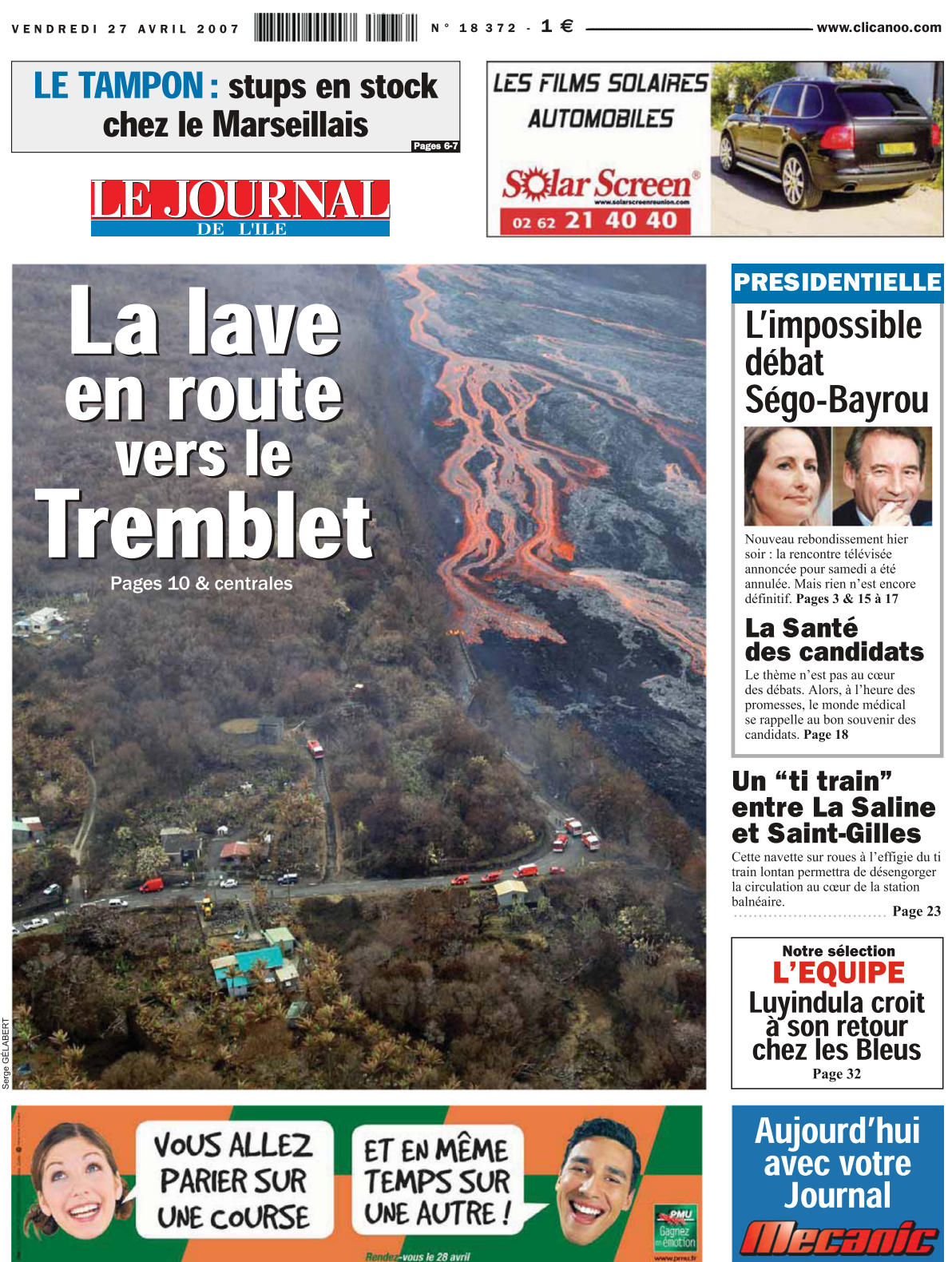

Fig. 11 Front page of JIR featuring the lava flow threat to the village of Le Tremblet published on 27 April 2007 ( $N^{\circ} 18372$ )

there had been no experience of gas emission and impact amongst the population or the journalist; for lava flows, there had been-it was a known quantity for which there was experience and memory so that frame was an informed one that was not associated with "fear" or "panic". All the same, advice regarding the gas and ash hazard was given in reports contained within the issues of 4 and 5 April, with further advice regarding health effects of sulfuric acid being provided by a lung specialist on 7 April. As we see next, the ash hazard was framed in a similar way, not being associated with the spectacle and sightseeing, but instead creating worry and uncertainty; worse "fear" and "panic".

\section{The ash frame}

The air fall problem became obvious on 4 April 2007, when the advice was communicated that young children should be kept inside, and fruit and vegetables taken from local allotments should be washed before consumption (Leyral 2007c). The sole front page devoted to the air fall hazard did not appear until two days later, featuring a man under an umbrella next to a bus stop with no other person in sight (Fig. 13). Hence, the flash tests for this returned responses such as "bus", "stop" and "umbrella" (Table 2). That the description of the problem was then left to a local resident, who was quoted as saying "there were lots (of Pele's hair) in the 


\section{VOLCAN}

QUATORZE ELEVES DE SAINT-JOSEPH CONDUITS A L'HOPITAL POUR DES GENES RESPIRATOIRES

\section{Un nuage de soufre cause un vent de panique}

Une cinquantaine d'adolescents incommodés, quatorze conduits vers les hôpitaux de Saint-Joseph et de Saint-Pierre. Tel est le bilan du passage d'un nuage de gaz volcanique sur le centre-ville de Saint-Joseph hier en début d'après-midi. Heureusement plus de peur que de mal.

\section{REPÈRE}

- LES CONSEILS DE LA PRÉFECTURE Face à l'éventualité volcanique, la préfecture invite les habitants de Saint-Joseph et SaintPhilippe à la plus grande prudence. Dans le communiqué envoyé hier aux médias les services de l'Etat recommandent " d'éviter toutes les activités ph siques et sportives intenses, augmentant de façon importante les volumes d'air et de pol luants inhales". Par préconise d'éviter d'em preconise d'eviter demchains jours des solvants jours des solvants et autres produits convient de "ne pas aggraver les effets cette pollution par a fumée du tabac, qui joue un rôle majeur dans la survenue de l'allergie respiratoire et de l'asthme".

\section{2}

Des parents prévenus au técher leurs enfants en catasSMUR envoyées sur place, piers de tout le Sud m aires de Saint-Joseph, des infirmeries qui débordent, le passage hier en début d'aprèsmidi d'un nuage de gaz volcanique a créé un véritable début de panique. Mais, fort heureusement quelques heures plus tard le bilan s'arete à une cinou moins fortement incommodés soufre dont quatorze ont été conduits vers les hôpitaux Saint-Pierre et de Saint-Joseph pour plus de prudence. Le responsable est tout désigné : le volcan. Plus particulièrement un nuage chargé $d$ soufre qui a été porté par les vents jusqu'au centre ville de Saint-Joseph, distant de moin d'une vingtaine de kilomètres. Un phénomène semble-t-1 très localisé qui a touché troi établissements scolaires : 1e collège Joseph-Hubert, le collège des Sang-Dragons et 1

\section{"LES LARMES}

\section{AUX YEUX"}

"Beaucoup d'élèves sont partis à l'infirmerie avec les larmes aux yeux, ils avaient $l$ a gorge qui grattait et un peu de mal à respirer, certains étaient tout rouges", témoigne un élève de Joseph-Hubert. Un établissement dont le principal n' " aucun commentaire a faire". Bien sûr, mais il y a eu d'adolescentse une dizaine quatre ont été coniqués dont pital. Au lycée voisin PierrePoivre, on relève seulement quatre jeunes touchés et deux qui ont dû être évacués. Le bilan est encore plus lourd du côté du collège SangDragons. Tout a commence vers $13 \mathrm{~h} 25$ explique la principale Marie-Jeanne Macé Linfirmerie $m$ 'a alerté car des eleves rencontraient des problèmes respiratoires et le plifié Quand je suis arrivé il avait une quarantaine d'élèves dont cinq vraiment gênés". Les secours ont déployé sur place des moyen très importants, toutes les casernes du Sud ont été mobilisées sous les ordres du commandant Vidot. Ses hommes sont intervenus également

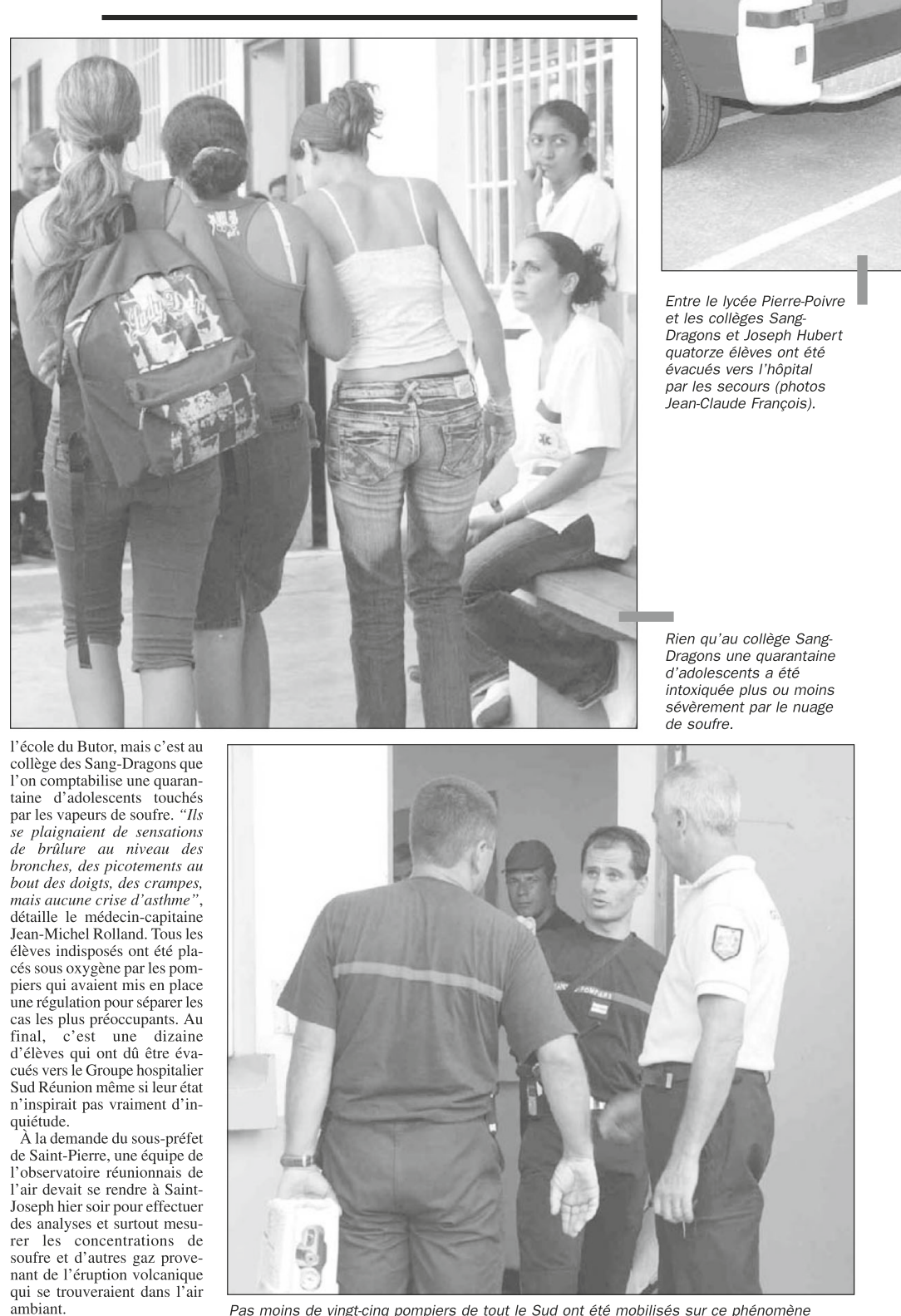

ambiant.

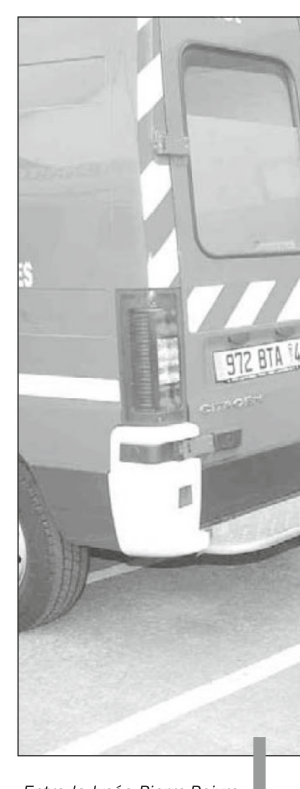

et les collèges SangDragons et Joseph Hubert quatorze élèves ont éter par les secours (photos

Fig. 12 Report and imagery from page 12 of JIR published on 4 April 2007 ( $N^{\circ} 18349$ ) illustrating the gas hazard 

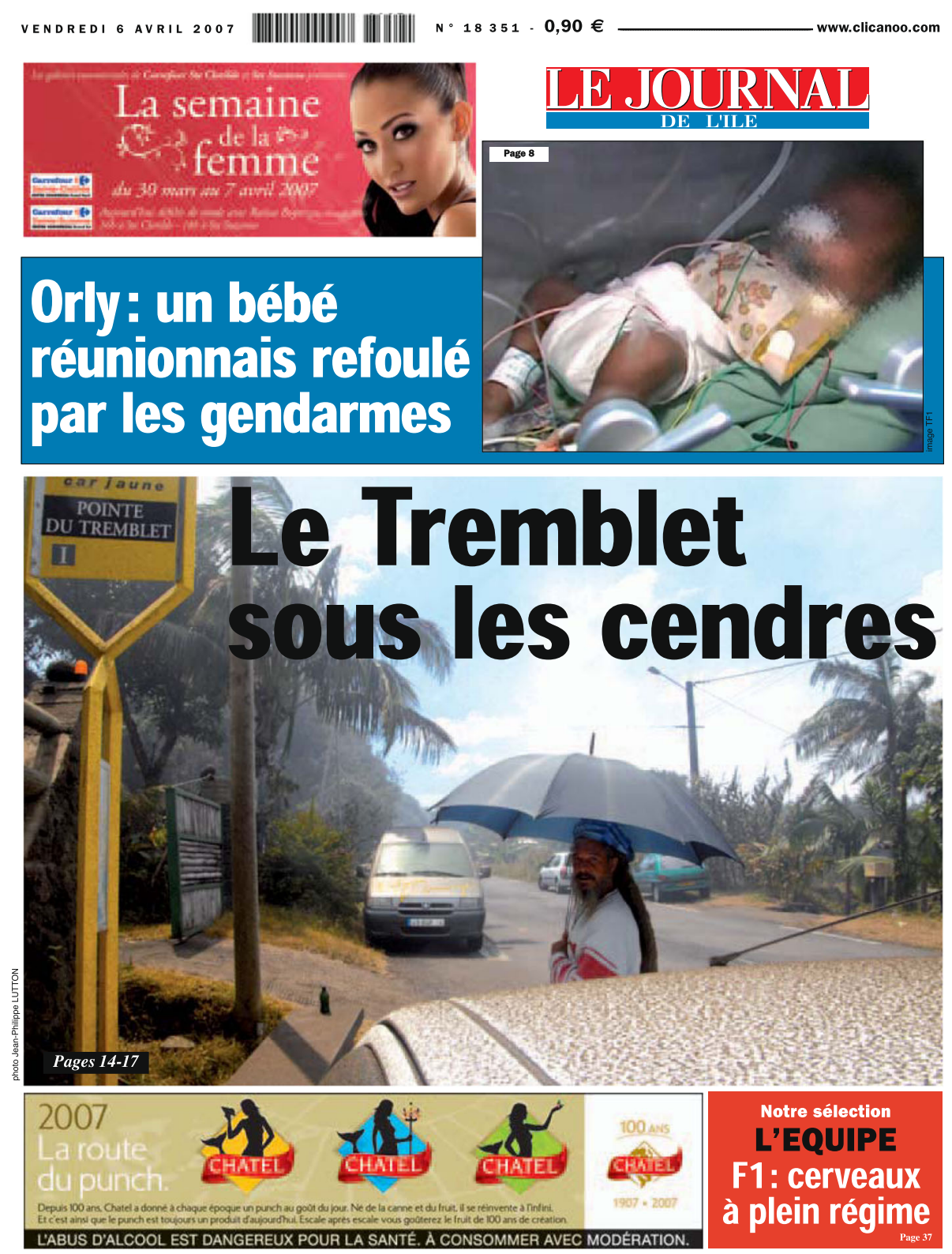

Fig. 13 Front page of JIR featuring the air fall hazard published on 6 April 2007 ( $N^{\circ}$ 18351)

town center and my car was covered" (Leyral 2007c), embodied the problem of framing this hazard. That is, it was framed in terms of the victims, and not the responders or decision makers. Indeed definition of, and ad-hoc responses to, the air fall hazard were spontaneous and developed by those subject to the hazard. For example, Leyral (2007b) reported,

"Pedestrians are rare. Those that adventure outside don't forget their umbrellas, not to protect themselves from the sun but above all from the continuous rain of cinder. Parked cars are covered by a mixture of
Pele's hair followed by ash, which makes the road surface particularly slippery."

Parallel with this was a feeling of unease among the resident population. For example, the lead-out paragraph of a full page article published on 6 April, entitled "Tremblet wakes under ash and fear", read (Leyral 2007b):

"An atmosphere of doom reigns over the village of Tremblet. After a sleepless night, people woke up yesterday under volcanic ash ......... Cut off from the 
world since Wednesday night, residents still live in fear of an eruption outside of 'L'Enclos'".

Resident quotes associated with this article included, "I was scared, but now I am OK", "I did not sleep all night", and "you know, one breathes anxiously here." On the same day, the following headline appeared at the top of page 18,

"The population split between worry and fascination"

This "fear", "scared", "anxious" and "worried" feeling led to descriptors such as "apocalyptic" being used, to cause a general atmosphere of unease and a feeling that this was "the end of the world". On 7 April, for example, one resident of Le Tremblet was quoted as saying, "It's not a volcano anymore; it's a monster." The same resident went on to say,

"Tonight, I prefer to stay at the gym. I do not want to sleep next to a 'thing' like that. I have my 83-year-old father with me, he trembles. My five-year-old daughter does not understand what is happening. She believes that the house will burn."

The following day, the experience of Le Tremblet was described under the headline "After hell, the desolation" (Lutton 2007a). Associating a hazard with names that convey fear, such as a monster, evil or the devil is not uncommon (Galli and Nigro 1987). The monster frame was not necessarily appreciated, with the following opinion piece appearing on page 24 of the 17 April edition:

\section{A monster ! \\ I heard the other night that the eruption of Piton la Fournaise was being presented on national TV with the statement "It's not a volcano anymore; it's a monster." The conclusion of this report once again makes local tourism professionals bristle. Tourism, following last year's problems of shark attacks, dog baiting, and the "chik" (i.e., the disease chikungunya), already gives the island a negative image in the Parisian media.}

All the same, those living in the impacted zone were genuinely scared and anxious. They thus needed reassurance, information and help. Thus the manner in which potential evacuation was communicated and executed became extremely important.

\section{The evacuation frame}

The evacuation of Le Tremblet on 6 April was framed extremely negatively, as witnessed by the lead headline on 7 April which read,

"Le Tremblet evacuated for nothing"
In the same report, a figure caption read "uncertainty dominated for part of the afternoon until a helicopter reconnaissance revealed that this was a false alarm" (Leyral et al. 2007a). During the evacuation reporting was again biased towards the viewpoints of the residents, there being 14 statements from residents of Le Tremblet in evacuation-related articles on 7 April, as opposed to two from the decision making authorities. In addition space set aside to reporting of the evacuation was $75 \%$ in favor of the resident population. As a result, the frame for the evacuation was very much set-up by the population themselves through publication of their quotes. These quotes paint a picture of a confused and poorly managed operation, with little recognition of the actual needs of the evacuees. The following examples are typical:

- " ........ we heard by word of mouth that it was necessary to evacuate" (Leyral et al. 2007a);

- "We had already prepared our things. But in the rush, in two minutes, we were just able to take the essentials: the dogs and a little linen" (Leyral et al. 2007a);

- "My moral is at zero. I am tired. Since they closed the road, we have been isolated from the world. We have no moral support. The mayor and the police pass in front of us without ever giving us news. We do not even know what will happen. The authorities do not inform us" (Anon 2007f);

- "It happened very quickly and brutally" (Leyral et al. 2007b);

- "The police went by saying 'leave.' But you understand I have a business. Later, others returned to tell us that there was no danger ......... I really left at the last (possible) moment" (Leyral et al. 2007b).

These impressions of "lack of information", "confusion", "rush" and "poor moral" contrasts with the picture portrayed by the authorities who claimed that the evacuation had been completed (Leyral et al. 2007a):

"calmly and in compliance with the scheme we had planned, namely following three evacuation stages from the most exposed area to the least exposed area ........ the most sensitive zone between Citrons Galets and Le Rempart was evacuated in ten minutes."

The prefecture concluded: "if it was a false alarm even better, it has shown us that the evacuation plan works very well". The next day some residents had some conciliatory words, one evacuated resident saying (Leyral 2007),

"The authorities were a bit rushed for a false alarm, but as they say prevention is better than a cure. Sure it was a little panicked, but it was better to do it by 
day rather than at night, that would have been disastrous."

Some displayed an optimistic mentality, with one resident arguing that with all of the rain that the area receives,

"I don't have any worries. Nature is too strong. She will quickly reclaim her rights."

Others stated that "we like our life here; the volcano doesn't make us scared; it's an old friend" (Lutton 2007b). However, the experience had been a severe shock, such that a team of psychologists was deployed on 11 April to work with the residents of Le Tremblet (Lutton 2007c). The prediction amongst the response workers arriving in Le Tremblet was that the residents (Lutton 2007c).

"will support very badly a wave of tourists armed with cameras to view the eruption. There will have to be a break in their suffering".

By 27 April the experience of the eruption and the evacuation had become so intense, after three weeks of "worry" and "stress" that one resident stated that (Anon 2007),

"we were happy to live here. But now if it is possible to sell the house and move away, I think we will leave with pleasure."

Another resident described a "crisis of nerves", adding that "I don't think I have the courage to go back." The article finishing with the statement that,

"It has been three weeks now that everyone has slept with one eye open."

Feelings in Le Tremblet were thus similar to those experienced in Kalapana (Kilauea, Hawaii) where residents having undergone an intensely stressful and shocking experience resented the intrusion of tourists, sightseers and media into their zone of personal distress; thus beginning to develop symptoms of post-traumatic stress syndrome (Weisel and Stapleton 1992). Probably, a frame whereby a page 9 headline on 7 April suggested that Le Tremblet was "at the gates of hell" likely did not help. As a result, residents suggested that the evacuation should have occurred by 5 April (Leyral 2007b), and a quarter of the population had already left of their own accord when the evacuation order was finally implemented (Leyral 2007c). Some of the evacuees then stayed where they were when the evacuation order was rescinded (Leyral et al. 2007a; Leyral 2007). The negative frame was not helped by a dichotomy in statements such as the situation in Le Tremblet was "hellish" and "catastrophic", while then claiming that the evacuation was "for nothing". Likewise the response plan was both described as "well-organized" and "poorly-implemented" at the same time.

\section{The ocean entry frame}

For the ocean entry, the front pages focused entirely on the "mysteries of the deep" and in particular on the exotic fish that were floating to the surface (Table 1), with the flash tests returning "mystery" and "fish" as the main impressions (Table 2). The ocean entry was thus framed as an interesting curiosity-almost a coup for Réunion-for which, although the hazards were stated, there was no suggestion of links with danger or risk. Under the title "Strange fish make the surface" Lauret (2007), for example, reported that,

"this is phenomenon that has not been described until yesterday. It could even be a first."

Likewise, the following day (Monday 10 April), a two page report under the title "The mysteries of the Abyss within reach" led with (Frasson-Botton 2007):

"Yesterday morning in St. Rose, scientists reiterated their miraculous catch of Sunday by collecting other species of dead fish that had ascended from the depths and were floating on the surface of the water, sometimes the species was unknown (about thirty species were collected). A remarkable side effect of the Fournaise (eruption), probably a first."

By 11 April, the "new, miraculous fish" had even attracted the attention of the Natural History Museum of Paris (Graignic 2007), with the "mystery of the abysses" frame continuing through 12 April. An article published on 15 April went as far as to celebrate a "discovery Réunionnaise." In contrast, the economic hardships of local fisherman, whose livelihood was at risk and to whom the loss of fisheries was an extreme concern (see Part 1), only received attention on the first day of the "hot water" story (9 April).

However, these events were certainly not the "first", "mysterious", "new" or a "discovery". During Fernandina's 1995 eruption lava entered the ocean to result in the death of at-least 15 species of fish as reported by McCosker et al. (1997). McCosker et al. (1997) wrote that, "in virile competition with feeding seabirds", they were able to capture a small sample of fish found dead or dying at the (ocean) surface. These fish died not just as a result of thermal effects, but also due to acoustic shock, dissolved chemicals, suspended sediments and embolism associated with rapid ascent, so that "most of 
the fish that possessed gas bladders exhibited such organisms distended from their mouths"; some, potentially, came from as deep as $1200 \mathrm{~m}$ (McCosker et al. 1997). Likewise in Hawaii, during ocean entry of Mauna Loa's 1950 eruption, Finch and Macdonald (1950) noted that "by 17:00 (on 2 June, 19 hours after the eruption had begun) a line of steaming water extended half a mile off shore. In this water zone many fish were killed, to be seen drifting or washed up onshore". The style of the coverage of the ocean entry during 2007 thus indicates excitement coupled with an ignorance regarding the process and its effects.

\section{The bench}

Upon ocean entry, lava flow into water creates what has become termed a "bench"; an extremely hazardous location due to its instability and associated explosive activity (Mattox and Mangan 1997). Collapses not only take large amounts of land-and all standing on it-with it, creating a local tsunami of hot water, but also trigger lava-water interaction explosions that send bombs and blocks inland and, potentially, into tourist viewing sites (Johnson et al. 2000). The first bench collapse during the 2007 eruption was reported on 25 April, as an aside to a two page photo montage dominated by spectacular color photographs of active lava at night. Other photos included pictures of boats, jet skis and paddle boarders around the steaming water off-shore of the ocean entry. As a minor addition to an article otherwise set aside to the on-going problems of Le Tremblet on 27 April, further bench collapses were reported to have occurred "at $12 \mathrm{~h} 30,16 \mathrm{~h}$ and 16h30" on the previous day. Thus, although bench collapse is a well-known hazard in Hawaii (Johnson et al. 2000) and which has caused casualties in the past at Kilauea (Perkins 2006), the bench completely lacked a hazard frame.

Defining, tracking and responding to frames during a volcanic emergency. Reese (2010) argues that framing is concerned with the way interests, communicators, sources and culture "combine to yield coherent ways of understanding the world". For Reese (2010), the success of framing depends on how comprehensively or completely the media source organizes information, and how persistent the frame is through time; that is, how routine is the format and structure of the frame. We provide here a simple methodology to define the components of Reese's (2010) frame for the front page of a newspaper during a volcanic crisis. Our analysis of the front pages of 120 consecutive editions of JIR published before, during and after the April 2007 eruption of Piton de la Fournaise reveals that its front page was designed to be the ideal vehicle for maximizing readership information delivery and recall of the event following the model of
Naccarato and Neuendorf (1998) and Neuendorf (2002), and hence delivering a frame that was routine and consistent in structure and format (Reese 2010). As a result, the stories of the day were always in predictable positions and organized in a routine hierarchy, so that the reader would know-through experience-where to look for most important news. Our flash tests also proved that the front page design was also successful in framing volcanic hazards in a way that the key elements of the story were held in the short-term memory. The components of this frame delivery involved:

(i) Headline placement was always at the top of the page, and involved an interleaved mixture of $4 \pm 2$ short- and medium-length words;

(ii) The story-of-the day was always written out as large font (with important words being capitalized and/or appearing first or last in the headline) in the center of the page;

(iii) A color image, usually containing a person, was always used to support the story-of-the day headline;

(iv) The image dominated the front page serving as the background and/or center-piece for all other elements.

From our flash tests, we find that the frame format defined was extremely effective in, in the words of Lippmann (1922), forming a consistent picture in the heads of the recipients regarding the volcanic hazards being reported. We have thus, here, provided an analysis framework that allows the way in which readers will receive and perceive information, communicated by newspapers during volcanic crises, to be defined and tracked.

Unfortunately, in the case study followed here, only the well-known (lava flow and pit crater) hazards were framed well. Gas, air fall and ocean entry hazards, as well as the evacuation plans and the decision making system, were very poorly framed. Having defined these frames the next question to ask is: what can the volcanologist do to respond to a developing frame? The answer is: support positive frames, while responding to negative frames through pre-emptive measures. Measures will include scientific advertising (Hopkins 1923), that reach the community exposed to the frame, and press releases (Lewis 2012) that target the journalists building the frame.

\section{Scientific advertising}

Business and industry often respond to negative frames, or take advantage of positive frames, through appropriately designed, timed and placed adverts (Harris 2015b). The same occurred in the cases examined here. On 10 April, the day after the fish story broke during the April 2007 eruption, an advert appeared on the same page as 
the fish story of that day by a garden depot offering special prices on various live, ornamental fish such as guppies and goldfish. We have already cited the adverts for over-flights of the Cratère Dolomieu following the collapse. We also note that adverts by various insurance companies offering coverage and banks offering loans following passage of cyclone Gamède, which caused extensive property damage across the island during 24-28 February 2007, ran throughout our study period, having begun to appear on 3 March, and running through mid-March.

Buying advertisement space may appear unethical or vulgar to the scientist, but there are other means of advertising such as setting up open houses, film shows, exhibitions, etc., and then advertising their content, location and times, or by offering useable editorial or review material to a journalist. Although probably not in response to the frames highlighted here, such an approach was in fact implemented during the 2007 eruption. Eruption-related adverts first appeared in the Agenda section of JIR (page 63) on 16 April. There were two. While the first advertised a temporary exhibition to be run at La Maison du Volcan between 21 April and 21 October 2007 entitled "30 years on from the 1977 lava"; the second advertised showing of a film covering "all of the stages" of the 2 April 2007 eruption at the same location. The launch of the exhibition, to mark the 30th anniversary of the 1977 eruption, was supported by a small piece on page 23 of the 17 April edition of JIR entitled a "special volcano evening" which would be held on 27 April. These adverts ran daily through 25 April. Whether chance or not, the event was a perfect and timely opportunity to outreach and educate. Special sections, supplements and Sunday magazines are other good places for scientific advertising. The Sunday Magazine ("Mag Dimanche") of JIR was used during April 2007 to inform on volcanic processes, being used on both the weekends of 7-8 April and 21-22 April. The Sunday Magazine is an 11 page supplement appearing in the middle of JIR each Sunday. It carried multiple page reviews of, and background on, topical newsworthy subjects, as well as health, cinema, book and music reviews. On 8 April, the Sunday Magazine featured a four-page-long review on the effects of, and response to, the 1977 effusive eruption of Piton de la Fournaise and its ingress into the town of Piton-Saint-Rose (pages 14-17). Then, on 22 April, a five-page review detailed the history of exploration of pit craters at the Cratère Dolomieu (pages 15-19). Unfortunately, though, only the well-known (lava flow and pit crater collapse) hazards were targeted. Given our content analysis, follow-up measures would have done well to educate, through web-site postings, public presentations, and fact sheet releases, on gas, air fall and ocean entry hazards as and when the hazards occurred, as well as to better communicate evacuation plans and the decision making system.

\section{Press releases: The need for outreach efforts to journalist during a volcanic crisis}

Although Russell (1986) identified that specialist science journalists generally have good scientific backgrounds, the non-specialist journalist may have difficulty understanding complex issues and interpreting numeric data (Voss 2002). Recognizing this problem, Smith et al. (2005) placed the onus on the scientist, suggesting that poor science writing could be improved if scientists "took the trouble" to communicate effectively with the journalists. As a result, Woloshin et al. (2009) argued that scientific bodies should work harder to promote accurate translation of output into news, while making it "easier for journalists to get it right" by ensuring that press releases routinely present and describe the situation. In fulfilling this need, Slovic (2000) recommended that scientists should understand that risk and uncertainty are inherently difficult to communicate, but that the media are the dominant source of risk information. Thus, Slovic (2000) argued, scientists should be proactive in enhancing science writing by educating reporters on the importance and subtleties of risk stories. Peters (1995) added that, while Journalists accept entertainment as a function of mass media more readily than scientists; scientists have little understanding of the journalistic need to attract and fascinate readers by means of certain stylistic elements. What these findings and recommendations amount to, are (i) if a need for information by the journalist is identified, (ii) the journalist should be approached, with (iii) information selected and presented in a way that is useful to, and useable by, the journalist. Tracking the frames developing during a volcanic crisis, and identifying the design of that frame, is a way to ensure that the information provided is appropriately selected and presented; an approach that understands the stylistic elements of the news design applied.

The formal means to outreach information to the mass media is through a press release, where Slovic (2000) recommended the development of science news clearinghouses, arguing that reporters need to know how and where to access relevant, knowledgeable and cooperative sources. On an agency or institutional level, this would be a press office or press officer-a point of contact that the journalist knows and trusts to be a pertinent information source. In the case followed here the frame that needed to be rectified was well-defined, the exact need for information was known and the publisher contactable, so that direct contact from the volcanologist to the journalist was the obvious option. In part 1 of this work, we identified the fact that reporting on Piton de la Fournaise's April 2007 eruption in JIR benefitted from the fact that specialist science writers were involved. Better, 
there was already a good relationship between the observatory and the journalist allowing direct and immediate communication, and that communication route was plainly used, there being almost daily quotes from OVPF staff and their bulletins in JIR (see Part 1). The key is, though, to identify the need for information and provide information that fills any knowledge gaps that develop.

\section{Conclusion}

Generally, as a gauge for information content, the front page of the JIR was always a mirror for its contents, with the frame delivered by the front page being supported by the responses of the flash tests. Although, as found in part one of this study, the quantity and quality of hazard information was excellent, the way in which it was framed was not so positive. Not surprisingly, hazards related to frequently experienced, and hence familiar, volcanic phenomena (lava flows and pit craters) were wellframed, but those relating to unfamiliar phenomena (widespread gas effects, air fall, evacuation and ocean entry/bench collapse) were not. Pit crater collapse and lava flow hazards were framed using their natural colors and using clear imagery of the phenomenon, althoughfor lava flows in particular-there was an element of spectacle and promotion of sightseeing. Gas and ash fall hazard became framed using images and words of the victims, so that it became worrying and frightening, and associated with panic. As a result, the volcano became framed as a monster and situation apocalyptic and hellish which, within the framework of SARF (Kasperson et al. 1988), amplified the risk and built fear. This probably contributed to the evacuation measures being framed as confused and pointless. In contrast, the ocean entry and bench collapse had no hazard-frame at all, and instead became associated with the exotic fish that bobbed to the surface. Thus, this volcanic process became attenuated to the point of it not existing as a risk; but being framed simply as a curiosity. This was due to the hazard being beyond the experience of the reporters.

In tracking the frames apparent in the media, there is an opportunity for the volcanology community to understand how people perceive volcanic hazard based on material published in the mass media during a volcanic crisis. We can use this knowledge to act on gaps and misconceptions that appear as they are published. If we have real-time knowledge, we can respond quickly through the use of internet (professional websites, professional social media accounts, etc.), addressing concerns at town hall meetings and (well-advertised) public presentations, and by contacting reporters with appropriately selected and presented information. In all cases, the needs, understanding, perception and concerns of the recipient will have been pre-empted through an appropriate analysis of information disseminated by the mass media and its frame.

\section{Additional files}

Additional file 1: Flash Tests - Group A.xlsx: Flash test results for Group
A (OVPF). (XLSX $16 \mathrm{~kb})$
Additional file 2: Flash Tests - Group B.xlsx: Flash test results for Group
B (Tourist Guides). (XLSX $61 \mathrm{~kb})$
Additional file 3: Flash Tests - Group C.Xlsx: Flash test results for Group
C (Students). (XLSX $111 \mathrm{~kb})$
Additional file 4: Piton April 2007 - Headline Analysis.Xlsx: Results of
headline analysis. (XLSX $113 \mathrm{~kb}$ )

\section{Acknowledgements}

We are extremely grateful to all participants in the flash tests for agreeing to participate and for consenting to use of the results. Two anonymous reviewers, and the associate editor (Ilan Kelman), provided excellent advice on how to better communicate this work and its implications. We are also exceedingly grateful Philippe Le Claire (Director of the JIR) for granting us permission for reproduction of JIR material and front pages in support of this scientific application. This is ANR-LAVA contribution no. 3.

\section{Funding}

This work was funded by the Agence National de la Recherche (ANR: www.agence-nationale-recherche.fr) through project ANR-LAVA (ANR Program: DS0902 2016; Project: ANR-16 CE39-0009, Link: www.agence-nationale-recherche.fr/?Project=ANR-16-CE39-0009).

\section{Availability of data and materials}

Raw data used here were PDF copies of the newspaper "Le Journal de L'lle de La Réunion" (JIR). These PDFs are available (for purchase) from https://www.payandread.fr/4DACTION/NewSwitchPublication?publicationID=18 https://www.clicanoo.re/. Argument support taken from each PDF is given as referenced. We provide here the results of our headline analysis which is given as an EXCEL spreadsheet in the electronic supporting material (Additional file 1). Also given in the electronic supporting material are the results of our flash tests for group A (Additional file 2: Group A), group B (Additional file 3: Group B) and group C (Additional file 4: Group A), with - for the sake of anonymity - all names removed.

\section{Authors' contributions}

Both authors have reviewed this manuscript and contributed to its content. Both authors read and approved the final manuscript.

\section{Competing interests}

The authors declare that they have no competing interests.

\section{Publisher's Note}

Springer Nature remains neutral with regard to jurisdictional claims in published maps and institutional affiliations.

\section{Author details}

${ }^{1}$ Université Clermont Auvergne, CNRS, IRD, OPGC, Laboratoire Magmas et Volcans, 6 Avenue Blaise Pascal, 63178 Aubière, France. ${ }^{2}$ Observatoire Volcanologique du Piton de la Fournaise, Institut de Physique du Globe de Paris, Sorbonne Paris Cité, CNRS, Université Paris Diderot, F-75005 Paris, France. ${ }^{3}$ Laboratoire GéoSciences Réunion, Université de La Réunion, Institut de Physique du Globe de Paris, Sorbonne Paris Cité, CNRS, F-97744, Saint Denis, France.

Received: 29 November 2017 Accepted: 10 April 2018 Published online: 31 May 2018

\section{References}

Anon Le Tremblet s'inquiète. Le JIR (vendredi 27 Avril 2007) No. 2007;18372: 10. Atkinson C. Beyond bullet points. Redmond: Microsoft Press; 2011. p. 330. Baddeley A. Working memory: theories, models and controversies. Annual. Rev Psychol. 2012;63:1-29.

Baddeley AD. How does acoustic similarity induce short-term memory. Q J Exp Psychol. 1968;20(3):249-64. 
Baddeley AD, Thomson N, Buchanan M. Word length and the structure of short-term memory. J Verbal Learn Verbal Behav. 1975;14:575-89.

Bogart L. Adult talk about newspaper comics. Am J Soc. 1955;61(1):26-30.

Campoy $\mathrm{G}$. The effect of word length in short-term memory: is rehearsal necessary? Q J Exp Psychol. 2008;61(5):724-34.

Carney RN, Levin JR. Pictorial illustrations still improve students' learning from text. Educ Psychol Rev. 2002;14(1):5-26.

Cater D. The fourth branch of government. Boston: Houghton Mifflin Company; 1959. $194 \mathrm{p}$

Cohen BC. The press and foreign policy. Princeton: Princeton University Press; 1963. $288 \mathrm{p}$

Cowan N. The magical number 4 in short-term memory: a reconsideration of mental storage capacity. Behav Brain Sci. 2000;24:87-185.

Dawson C, Lyons $\mathrm{H}$. The media and the market: the case of CJD. Br Food J. 2003:105(6):380-94.

Della Sala S, van der Muelen M, Bestelmeyer P, Logie RH. Evidence for a workspace model of working memory from semantic implicit processing in neglect. J Neurpsychology. 2010;4:147-66.

Dirkson J. Design for how people learn. Berkely: New Riders; 2012. p. 259.

Duarte N. slide:ology. O'Rielly (Beijing): 2008;274 .

Dupuis A, Martel-Asselin F. Les 100 visages du piton de la Fournaise. Le Journal de L'lle de La Réunion (mercredi 11 Avril 2007). 2007;18356: 12-13.

Dutrow BL. Visual communication: do you see what I see? Elements. 2007;3(2): 119-26.

Ebbinghaus H. Memory. Translated by HA Ruger \& CE Bussenius (1913), Columbia Univseristy (New York): 1885;123.

Entman RM. Projections of power: framing news, public opinion and U.S. foreign policy. Chicago: University of Chicago Press; 2004. p. 229.

Finch RH, Macdonald GA. The June 1950 eruption of Mauna Loa part I: narrative of the eruption. Volcano Lett. 1950;508:1-12.

Frasson-Botton. Les mystères des abysses à portée de main. Le Journal de L'lle de La Réunion (mardi 10 Avril 2007). 2007;18355: 10-11.

Galli I, Nigro G. The social representation of radioactivity among Italian children. Soc Sci Inf. 1987;26(3):535-49.

Glanzer M, Cunitz AR. Two storage mechanisms in free recall. J Verbal Learn Verbal Behav. 1966:5:351-60.

Graignic B. "Il faudra des mois avant de tirer des conclusions" Le Journal de L'Ile de La Réunion (mercredi 11 Avril 2007) 2007;18356: 11.

Harcup T. Journalism: principles and practice. 2nd ed. Los Angeles: Sage; 2009. p. 244.

Harris AJL. Forecast communication through the newspaper part 1: framing the forecaster. Bull Volcanol. 2015a;77:29. https://doi.org/10.1007/s00445-015-0899-x.

Harris AJL. Forecast communication through the newspaper part 2: perceptions of uncertainty. Bull Volcanol. 2015b;77:30. https://doi.org/10.1007/s00445-015-0902-6.

Harris AJL, Villeneuve N. Newspaper reporting of the April 2007 eruption of Piton de la Fournaise Part 1: Useful information or tabloid sensationalism? Applied Volcanology. 2018. https://doi.org/10.1186/s13617-018-0072-2.

Höijer B, Lidskog R, Thornberg L. News media and food scares: the case of contaminated salmon. Environ Sci. 2006;3(4):273-88.

Hopkins CC. Secientific advertising. New York: Cosimo; 1923. p. 95. (2010 reprint)

Johnson J, Brantley SR, Swanson DA, Stauffer PH, Hendley JW. Viewing Hawai'i's lava safely_common sense is not enough. USGS Fact Sheet. 2000:152-00. 4 p

Kahneman D, Tversky A. Choices, values and frames. AmPsychol. 1984;39(4):341-50.

Kasperson JX, Kasperson RE. The social amplification and attenuation of risk. Ann Am Academy of Political Social Sci. 1996;545:95-105.

Kasperson JX, Kasperson RE, Slovic P. The social amplification of risk: assessing fifteen years of research and theory. In: Pidgeon N, Kasperson RE, Slovic P, editors. The social amplification of risk. Cambridge: Cambridge University press; 2003. p. 156-78.

Kasperson RE. The social amplification of risk: progress in developing an integrative framework of risk. In: Krimsky S, Golding D, editors. Social theories of risk. Westport: Praeger; 1992. p. 153-78.

Kasperson RE, Renn O, Slovic P, Brown HS, Emel J, Goble R, Kasperson JX, Ratick S. The social amplification of risk: a conceptual framework. Risk Anal. 1988;8(2):177-87.

Katzman N. Television soap operas: what's been going on anyway? Public Opin Q. 1972;36(2):200-12.

Lauret T. D'étranges poissons font surface. Le Journal de L'lle de La Réunion (lundi 9 Avril 2007) 2007;18354: 8.

Lewis S. How to write the perfect press releases. How-to guides. Taleist (Mareston Gate, UK): 2012;90.

Leyral P. Les exilés du volcan ont pu enfin dormir. Le Journal de L'lle de La Réunion (samedi 26 Mai 2007) 2007;18353: 14.
Leyral P. Un nuage de soufre cause un vent de panique. Le Journal de L'lle de La Réunion (mercredi 4 Avril 2007) 2007a;18349: 12.

Leyral P. Le Tremblet se réveille sous les cendres et dans la crainte. Le Journal de L'lle de La Réunion (jeudi 6 Avril 2007) 2007b;18351: 14

Leyral P. Des cheveux de Pélé sur tout le Sud. Le Journal de L'lle de La Réunion (mercredi 4 Avril 2007) 2007c;18349: 13.

Leyral P, Lutton J-P, François J-C. Le Tremblet évacué pour rien. Le Journal de L'lle de La Réunion (samedi 7 Avril 2007) 2007a;18352: 7.

Leyral P, Lutton J-P, François J-C. "Ce n'est plus un volcan, C'est un monstre". Le Journal de L'lle de La Réunion (samedi 7 Avril 2007) 2007b;18352: 10.

Lippmann W. Public opinion BN Publications (2008 reprint): 1922;319.

Lutton J-P. Après l'enfer, la désolation. Le Journal de L'lle de La Réunion (dimanche 8 Avril 2007) 2007a;18353: 12

Lutton J-P. Le Tremblet retrouve son calme dans un décor lunaire. Le Journal de L'lle de La Réunion (mardi 10 Avril 2007) 2007b;18355: 9.

Lutton J-P. "Nous étions des pestiférés". Le Journal de L'lle de La Réunion (jedui 12 Avril 2007) 2007c;18357: 8.

Martel-Asselin, F. Les séismes s'intensifient. Le Journal de L'lle de La Réunion (jeudi 29 Mars 2007);2007a;18343: 6.

Martel-Asselin, F. Le volcan devient-il fou?. La guerre du feu et de l'eau. Le Journal de L'lle de La Réunion (mercredi 4 Avril 2007) 2007b;18349: 11.

Martel-Asselin, F. Les séismes s'intensifient. Le Journal de L'lle de La Réunion (jeudi 29 Mars 2007) 2007c;18343: 6

Martin-Lagardette J-L. Le guide de l'écriture journalistique. 7th ed. Paris: La Découverte; 2009. p. 255

Mattox TN, Mangan MT. Littoral hydrovolcanic explosions: a case study of lavaseawater interaction at Kilauea volcano. J Volcanol Geotherm Res. 1997;75:1-17.

Mayer RE, Anderson RB. The instructive animation: helping students build connections between words and pictures in multimedia learning. J Educ Psychol. 1992:84(4):444-52.

Mayer RE, Syms RK. For whom is a picture worth a thousand words? Extensions of a dual-coding theory of multimedia learning. J Educ Psychol. 1994;86(3): 389-401.

McCombs M. Setting the agenda. Malden: Polity Press; 2014. 209 p

McCombs M, Shaw DL. Agenda-setting function of mass media. Publ Opin Q. 1972;36(2):176-87.

McCosker JE, Godfrey M, Long JD, Gilmore RG, Villon C. Deepslope fishes collected during the 1995 eruption of Isla Fernandina. Galapagos, Noticias de Galapagos. 1997;58:22-6.

Morris MW, Peng K. Culture and cause: American and Chinese attributions for social and physical events. J Pers Soc Psychol. 1994;67(6):949-71.

Naccarato JL, Neuendorf KA. Content analysis as a predictive methodology: recall, readership, and Evaiuations of business-to-business print advertising. J Advertising Res. 1998;38(3):19-33.

Neath I, Nairne JS. Word-length in immediate memory: overwriting trace decay theory. Psychon Bull Rev. 1995;2(4):429-41.

Neisser U, Kerr N. Spatial and mnemonic properties of visual images. Cogn Psychol. 1973;5:138-50.

Neuendorf KA. The content analysis guidebook. Thousand Oak: Sage; 2002. p. 301.

Paivio A, Caspo K. Picture superiority in free recall: imagery or dual coding? Cogn Psychol. 1973;5(2):176-206.

Payet G. Les Réunionnais et leur Volcan. Antenne Reunionnaise de I'Institut de Victimologie. 2007;147.

Perkins MC. Surviving Paradise. Quidnunc Press (USA): 2006. p. 338.

Peters HP. The interaction of journalists and scientific experts: cooperation and conflict between two professional cultures. Media Culture Soc. 1995;17:31-48.

Reese SD. Framing public life: a bridging model for media research. In: Reese SD, Gandy Jr OH, Grant AE, editors. Framing public life. New York: Routledge; 2010. p. 7-31.

Reese SD, Gandy OH Jr, Grant AE. Framing public life. New York: Routledge; 2010. 399 p

Reynolds G. Presentation zen design. USA: New Riders; 2014. p. 277.

Rosten LC. The Washington correspondents. New York: Harcourt, Brace and Company; 1937. p. 426.

Rowe G, Frewer L, Sjoberg L. Newspaper reporting of hazards in the UK and Sweden. Public Underst Sci. 2000:9:59-78.

Russell C. The view from the national beat. In: Friedman SM, Dunwoody S, Rogers $\mathrm{CL}$, editors. Scientists and journalists: reporting science as news. New York: The Free Press; 1986. p. 81-94.

Slovic P. Informing and educating the public about risk. In: Slovic P, editor. The perception of risk. Trowbridge: Earthscan publications; 2000. p. 182-98. 
Smith DE, Wilson AJ, Henry DA. Monitoring the quality of medical news reporting: early experience with media doctor. MJA. 2005;183(4):190-3. Standing L. Learning 10,000 pictures. Q J Exp Psychol. 1973;25:207-22.

Standing L, Conezio J, Haber RN. Perception and memory for pictures: single-trial learning of 2500 visual stitlluli. Psychon Sei. 1972;19(2):73-4.

Staudacher T, Ferrazzini V, Peltier A, et al. The April 2007 eruption and the Dolomieu crater collapse, two major events at piton de la Fournaise (La Réunion Island, Indian Ocean). Recent Adv Geodyn. 2009;184:126-37. https://doi.org/10.1016/j.jvolgeores.2008.11.005.

Staudacher T, Ruzié L, Peltier A. Historique des éruptions du Piton de la Fournaise de 1998 à 2007. Graphica (St Denis, La Réunion): 2008;97.

Tulving E. Ebbinghaus's memory: what did he learn and remember? J. Exp Psychol. 1985;11(3):485-190.

Voss M. Checking the pulse: midwestern reporters' opinions on their ability to report health care news. Am J Public Health. 2002:92:1158-60.

Vu HT, Guo L, McCombs ME. Exploring "the world outside and the pictures in our heads": a network agenda-setting study. J Mass Commun Q. 2014;91:669-86. https://doi.org/10.1177/1077699014550090.

Wallis P, Nerlich B. Disease metaphors in new epidemics: the UK media framing of the 2003 SARS epidemic. Soc Sci Med. 2005;60(1):2629-39. https://doi.org/ 10.1016/j.socscimed.2004.11.031.

Washer P. Representations of SARS in the British newspapers. Soc Sci Med. 2004;59:2561-71

Weisel D, Stapleton F. Aloha O Kalapana. Bishop Museum Press (Honolulu): 1992153.

Wickelgren WA. Short-term memory for phonemically similar lists. Am J Psychol. 1965;78(4):567-74.

Woloshin SW, Schwartz LM, Kramer BS. Promoting healthy skepticism in the news: helping journalists get it right. J Nat Cancer Inst. 2009;101(23):1596-9.

\section{Submit your manuscript to a SpringerOpen ${ }^{\circ}$ journal and benefit from:}

- Convenient online submission

- Rigorous peer review

- Open access: articles freely available online

- High visibility within the field

- Retaining the copyright to your article

Submit your next manuscript at $>$ springeropen.com 